\title{
Impacts of global, regional, and sectoral black carbon emission reductions on surface air quality and human mortality
}

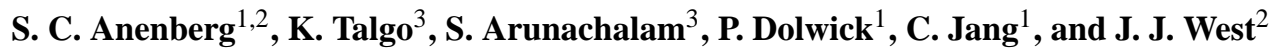 \\ ${ }^{1}$ US Environmental Protection Agency, 109 TW Alexander Dr., Research Triangle Park, NC 27711, USA \\ ${ }^{2}$ Departmnt of Environmental Sciences and Engineering, University of North Carolina at Chapel Hill, Chapel Hill, NC, USA \\ ${ }^{3}$ Institute for the Environment, University of North Carolina at Chapel Hill, Chapel Hill, NC, USA
}

Received: 20 March 2011 - Published in Atmos. Chem. Phys. Discuss.: 5 April 2011

Revised: 12 July 2011 - Accepted: 14 July 2011 - Published: 25 July 2011

\begin{abstract}
As a component of fine particulate matter $\left(\mathrm{PM}_{2.5}\right)$, black carbon (BC) is associated with premature human mortality. BC also affects climate by absorbing solar radiation and reducing planetary albedo. Several studies have examined the climate impacts of $\mathrm{BC}$ emissions, but the associated health impacts have been studied less extensively. Here, we examine the surface $\mathrm{PM}_{2.5}$ and premature mortality impacts of halving anthropogenic $\mathrm{BC}$ emissions globally and individually from eight world regions and three major economic sectors. We use a global chemical transport model, MOZART-4, to simulate $\mathrm{PM}_{2.5}$ concentrations and a health impact function to calculate premature cardiopulmonary and lung cancer deaths. We estimate that halving global anthropogenic $\mathrm{BC}$ emissions reduces outdoor population-weighted average $\mathrm{PM}_{2.5}$ by $542 \mathrm{ng} \mathrm{m}^{-3}(1.8 \%)$ and avoids 157000 (95\% confidence interval, 120000-194000) annual premature deaths globally, with the vast majority occurring within the source region. Most of these avoided deaths can be achieved by halving emissions in East Asia (China; $54 \%$ ), followed by South Asia (India; $31 \%$ ), however South Asian emissions have $50 \%$ greater mortality impacts per unit $\mathrm{BC}$ emitted than East Asian emissions. Globally, halving residential, industrial, and transportation emissions contributes $47 \%$, 35\%, and $15 \%$ to the avoided deaths from halving all anthropogenic BC emissions. These contributions are 1.2, 1.2, and 0.6 times each sector's portion of global BC emissions, owing to the degree of co-location with population globally. We find that reducing $\mathrm{BC}$ emissions increases regional $\mathrm{SO}_{4}$ concentrations by up to $28 \%$ of the magnitude of the regional $\mathrm{BC}$ concentration reductions, due to reduced absorption of radiation that drives photochemistry. Impacts of residential $\mathrm{BC}$ emissions are likely underestimated since indoor $\mathrm{PM}_{2.5}$
\end{abstract}

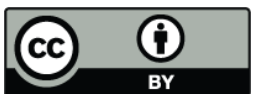

Correspondence to: J. J. West (jjwest@email.unc.edu) exposure is excluded. We estimate $\sim 8$ times more avoided deaths when $\mathrm{BC}$ and organic carbon (OC) emissions are halved together, suggesting that these results greatly underestimate the full air pollution-related mortality benefits of $\mathrm{BC}$ mitigation strategies which generally decrease both $\mathrm{BC}$ and OC. The choice of concentration-response factor and health effect thresholds affects estimated global avoided deaths by as much as $56 \%$ but does not strongly affect the regional distribution. Confidence in our results would be strengthened by reducing uncertainties in emissions, model parameterization of aerosol processes, grid resolution, and $\mathrm{PM}_{2.5}$ concentration-mortality relationships globally.

\section{Introduction}

Black carbon (BC) is a component of fine particulate matter $\left(\mathrm{PM}_{2.5}\right)$ produced by incomplete combustion of fuel and is mainly emitted by residential, transportation, and industrial sources (Bond et al., 2004). $\mathrm{PM}_{2.5}$ is associated with negative health impacts, including premature mortality (e.g. Krewski et al., 2009), and some evidence suggests that $\mathrm{PM}_{2.5}$ mixtures containing high $\mathrm{BC}$ fractions may have larger mortality effects than other mixtures (Smith et al., 2009). BC also warms the atmosphere by absorbing solar radiation (e.g. Horvath, 1993), indirectly impacts cloud lifetime and reflectivity (Koch and Del Genio, 2010), and deposits on snow and ice, reducing albedo and quickening melting (e.g. Hansen and Nazarenko, 2004). Although the net effects of $\mathrm{BC}$ on climate remain uncertain, mitigation of $\mathrm{BC}$ emissions offers an opportunity to address climate change and air pollution simultaneously (e.g. Jacobson, 2002; Bond and Sun, 2005; Ramanathan and Carmichael, 2008; Kopp and Mauzerall, 2010). Both climate and health benefits should therefore be considered when evaluating mitigation strategies. 
While several recent studies have examined the climate impacts of BC emissions (e.g. Koch et al., 2007; Reddy and Boucher, 2007; Levy et al., 2008; Shindell et al., 2008; Fuglestvedt et al., 2010), the associated health impacts have been studied less extensively. In contrast with direct atmospheric warming by $\mathrm{BC}$ absorption of sunlight, which depends on total column $\mathrm{BC}$ concentrations, $\mathrm{BC}$ health impacts depend on population exposure at the surface, where humans breathe. In addition, the net climate impacts of $\mathrm{BC}$ emitting sources can be offset by co-emitted $\mathrm{PM}_{2.5}$ components that reflect radiation, such as organic carbon (OC) and sulfate $\left(\mathrm{SO}_{4}\right.$; Unger et al., 2010), but all $\mathrm{PM}_{2.5}$ components are thought to be damaging to health (e.g. Krewski et al., 2009). Since the drivers for climate and health impacts of $\mathrm{BC}$ emissions differ, mitigation strategies that achieve the greatest near-term climate benefits may not yield the greatest co-benefits for public health, and vice versa.

Previous studies of the health impacts of outdoor air pollution have found that the greatest burden of outdoor air pollution on human health occurs in Asia, where large populations are exposed to high ozone and $\mathrm{PM}_{2.5}$ concentrations (Cohen et al., 2004; Anenberg et al., 2010), and that biofuel combustion causes eight times more premature deaths globally than fossil fuel emissions, largely because biofuel combustion occurs mainly in very populated regions of the world (Jacobson, 2010). Surface BC concentrations, specifically, have also been found to be highest over East Asia, South Asia, and Southeast Asia (e.g. Koch et al., 2009). The co-location of high BC concentrations and large populations may translate into a substantial impact on global public health, and significant potential benefits of $\mathrm{BC}$ mitigation.

Quantifying the health benefits of $\mathrm{BC}$ emission reductions and their variation by source region and sector may inform strategies to mitigate near-term climate change and air pollution simultaneously. Here, we calculate the surface air quality and premature human mortality impacts of halving anthropogenic $\mathrm{BC}$ emissions globally, regionally, and from three major economic sectors. We also examine a scenario in which $\mathrm{BC}$ and $\mathrm{OC}$ emissions are reduced together, as they are co-emitted and likely to both be affected by BC mitigation strategies. We simulate $\mathrm{PM}_{2.5}$ concentration changes with a global chemical transport model (CTM) and calculate mortality changes using a health impact function based on epidemiologically-derived concentration-response relationships.

\section{Methods}

\subsection{Model setup}

We simulate a base case and several sensitivity cases using the global CTM MOZART-4 (Model of Ozone And Related Tracers, version 4; Emmons et al., 2010b). MOZART-4 has 85 gas-phase species and 39 photolysis and 157 gas-phase reactions. The representation of tropospheric aerosols includes sulfate $\left(\mathrm{SO}_{4}\right.$; assumed here to exist as ammonium sulfate), BC, OC, secondary organic aerosol (SOA), ammonium nitrate $\left(\mathrm{NO}_{3}\right)$, and sea salt (Emmons et al., 2010b). Here, MOZART-4 is configured with a horizontal resolution of $1.9^{\circ} \times 1.9^{\circ}, 28$ vertical levels, and is driven with meteorology from the NCEP/NCAR reanalysis ( $6 \mathrm{~h}$ timestep; Kalnay et al., 1996; Kistler et al., 2001) for the year 2002 with six months of spinup starting in July 2001. An online photolysis scheme accounts for the impact of aerosols on photolysis rates, affecting production of photochemical oxidants (Tie et al., 2005; Emmons et al., 2010b), however, aerosol feedback on meteorology (including atmospheric circulation and interactions with clouds) is excluded. BC and OC are initially emitted as $80 \%$ and $50 \%$ hydrophobic and are converted to hydrophilic with a time constant of 1.6 days to simulate the gradual coating of hydrophobic particles with sulfate and other compounds (Emmons et al., 2010b). Dry deposition of $\mathrm{BC}$ and $\mathrm{OC}$ is set to $0.1 \mathrm{~cm} \mathrm{~s}^{-1}$ and wet deposition of hydrophilic $\mathrm{BC}$ and $\mathrm{OC}$ is set to $20 \%$ of the wet deposition rate of $\mathrm{HNO}_{3}$ (Tie et al., 2005; Emmons et al., 2010b).

Anthropogenic BC and OC emissions for the year 2000 are from the inventory developed for the Intergovernmental Panel on Climate Change Fifth Assessment Report (IPCC AR5), based on Bond et al. (2007) and Junker and Liousse (2008) with updates described by Lamarque et al. (2010). Since this inventory includes only submicron particles, we multiply BC and OC emissions by 1.15 and 1.4 to include all particles up to $2.5 \mu \mathrm{m}$ in diameter for these species (Cooke et al., 1999), as in Liu et al. (2009a). The IPCC AR5 inventory reports emissions from the residential, transportation, and industrial sectors (includes non-road transportation), and smaller sectors, such as waste treatment, agricultural waste burning, and shipping. The residential, industrial, and transportation sectors together comprise $>90 \%$ of the total anthropogenic BC inventory (Fig. 1). As BC and $\mathrm{OC}$ are generally co-emitted with $\mathrm{CO}$ (e.g. Dickerson et al., 2002), we vary these emissions monthly by scaling to the monthly profile of $\mathrm{CO}$ from the RETRO emissions inventory (http://retro.enes.org/data_emissions.shtml), which does not include $\mathrm{BC}$ and $\mathrm{OC}$, in each grid cell and sector (Figs. S1-S2).

Anthropogenic emissions of all other species are those used by Emmons et al. (2010b), which are from the POET (Precursors of Ozone and their Effects in the Troposphere; Olivier et al., 2003; Granier et al., 2005) inventory for the year 2000, with Asian emissions replaced by the annually varying Regional Emissions Inventory in Asia (REAS; Ohara et al., 2007) (Table S1). Biomass burning emissions for all species are from the Global Fire Emissions Database version 2 (GFED2; van der Werf et al., 2006) for the specific months in 2001 and 2002 modeled here. To account for emission altitude and plume buoyancy, we distribute all biomass burning emissions vertically up to $6 \mathrm{~km}$ above the surface using the vertical profile from Dentener et al. (2006). All 


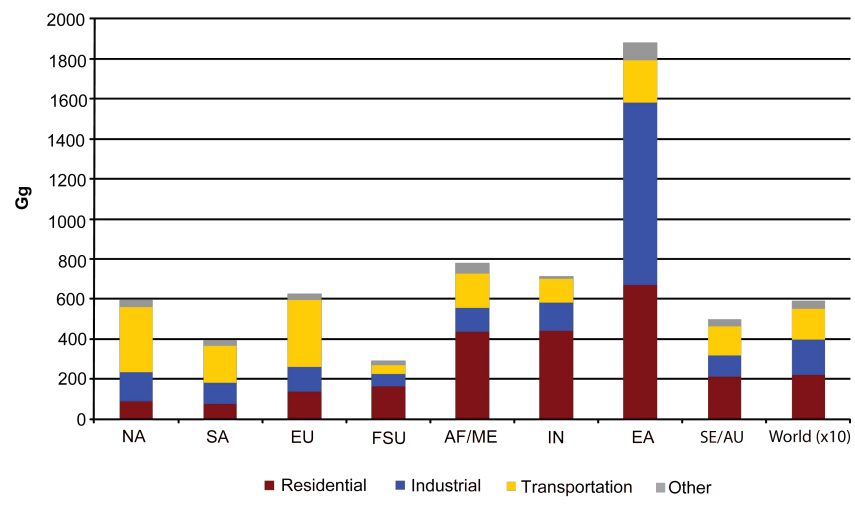

Fig. 1. Anthropogenic $\mathrm{BC}$ emissions by region and sector after the IPCC emissions are scaled by 1.15 to account for particles larger than $1 \mu \mathrm{m}$ in diameter. World emissions are shown divided by 10 to fit on the scale.

other emissions are injected at the surface, including power generation $(<1 \%$ of global $\mathrm{BC}$ emissions) and industrial emissions, which include non-road transportation and small sources with no smokestacks.

Relative to this base case, we calculate changes in $\mathrm{PM}_{2.5}$ concentration and mortality for 12 sensitivity cases wherein anthropogenic BC emissions are halved globally, individually in eight major world regions (North America, South America, Europe, the Former Soviet Union, Africa/Middle East, South Asia (India), East Asia (China), and Southeast Asia/Australia) and individually in three major economic sectors (residential, industrial, transportation). These regions are defined in Table 1 and Fig. S3. The 50\% reductions are chosen to simulate realistic but ambitious policy targets, while producing changes in $\mathrm{PM}_{2.5}$ that are sufficiently large to be analyzed in all reduction scenarios. We also examine a scenario in which global anthropogenic $\mathrm{BC}+\mathrm{OC}$ emissions are halved together, since they are co-emitted. Because each emissions source emits $\mathrm{BC}$ and $\mathrm{OC}$ in different ratios and each control measure may reduce them in different percentages, this experiment is meant to be illustrative of including OC reductions and does not represent the impacts of actual mitigation measures. Finally, to isolate the impact of emissions in the United States (US), we examine a scenario in which $\mathrm{BC}$ emissions are halved in the US only and compare the results with the North American reduction in the Supplement. We use simulated concentrations in the first vertical level (height $=\sim 80 \mathrm{~m}$ ) as surface concentrations. We multiply simulated hydrophobic and hydrophilic OC concentrations by 1.3 and 1.7 to account for associated species other than carbon (Ming et al., 2005) and add this to SOA to give total organic mass (OM). We estimate $\mathrm{PM}_{2.5}$ as $\mathrm{BC}+\mathrm{OM}+\mathrm{SO}_{4}+\mathrm{NO}_{3}$, assuming that these species exist entirely as $\mathrm{PM}_{2.5}$ and ignoring other species (dust and sea salt) that are dominated by natural emissions and are unaffected by changing $\mathrm{BC}$ and $\mathrm{OC}$ emissions.

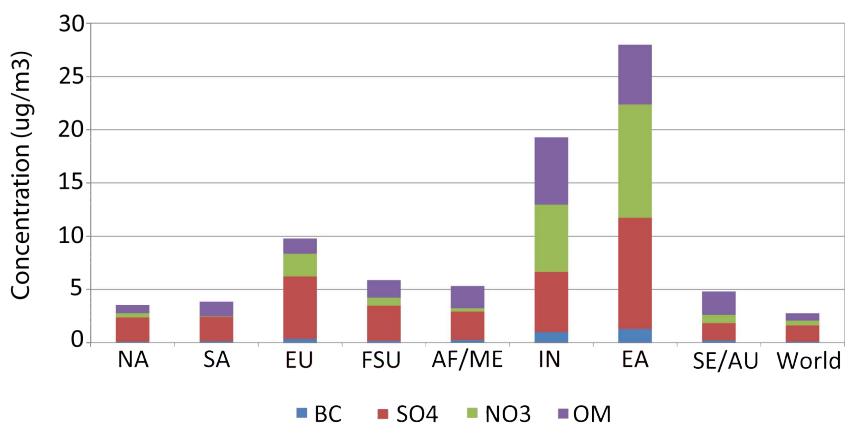

Fig. 2. Simulated annual average concentration $\left(\mu \mathrm{g} \mathrm{m}^{-3}\right)$ of $\mathrm{PM}_{2.5}$ components for the base case (2002) by geographic region.

\subsection{Evaluation of base case surface concentrations}

Simulated annual average $\mathrm{PM}_{2.5}$ concentrations are highest in EA and IN, due to large anthropogenic and biomass burning emissions (Table 1 and Figs. S4-S8). BC is 3-5\% of total $\mathrm{PM}_{2.5}$ among world regions and $\mathrm{OM}$ is $14-46 \%$ (Fig. 2 and Table S2). $\mathrm{SO}_{4}$ generally contributes the most to $\mathrm{PM}_{2.5}$, except for IN and EA, where $\mathrm{OM}$ and $\mathrm{NO}_{3}$ also contribute significantly, and SE/AU, where OM is high due to wildfires. Population-weighted average concentrations of all species are 1.2-3.3 times larger than simple average concentrations, reflecting co-location of emissions and concentrations with population (Table S2).

MOZART-4 has been evaluated extensively against satellite data and measurements at altitude and at the surface by Emmons et al. (2010b) and Tie et al. (2005), who comprehensively evaluated the aerosol scheme specifically. Here we focus on changes in $\mathrm{PM}_{2.5}$ components at the surface, and therefore evaluate simulated $\mathrm{BC}, \mathrm{OC}$, and $\mathrm{SO}_{4}$ concentrations in the first vertical level. Since modeled concentrations are volume averages over large grid cells, they are expected to represent concentrations in remote locations that are more homogenous better than in urban areas. We therefore compare simulated concentrations to surface observations mainly in remote locations from the Interagency Monitoring of Protected Visual Environments (IMPROVE; http://vista.cira.colostate.edu/improve/) network for the US (134 monitors) and the European Monitoring and Evaluation Programme (EMEP; http://www.emep.int/) network for Europe (13 monitors for $\mathrm{BC}$ and $\mathrm{OC}, 75$ for $\mathrm{SO}_{4}$ ). Although we simulate 2002 for our base case, for the model evaluation only, we ran the base case through 2003 to leverage additional observations from IMPROVE (available for both 2002 and 2003) and EMEP (available for July 2002-June 2003). We also compare modeled $\mathrm{BC}$ and $\mathrm{OC}$ with observations at 15 locations in China (Zhang et al., 2008) and eight in India (Beegum et al., 2009) from 2006. All of these monitoring networks report elemental carbon (EC), which is measured by optical rather than thermal-optical techniques and may be between $30 \%$ and $100 \%$ of BC; since the emissions 
Table 1. Simple and population-weighted annual average $\mathrm{PM}_{2.5}\left(\mathrm{ng} \mathrm{m}^{-3}\right)$ concentrations for the base case and $\mathrm{PM}_{2.5}$ reduction, avoided cardiopulmonary and lung cancer deaths (in thousands), and percent of these deaths from cardiopulmonary (CP) disease due to halving global anthropogenic BC emissions and BC + OC emissions. Confidence intervals (95\%, in parentheses) reflect uncertainty in the CRF only.

\begin{tabular}{|c|c|c|c|c|c|c|c|c|c|c|}
\hline \multirow[b]{2}{*}{$\begin{array}{l}\text { Receptor } \\
\text { region }\end{array}$} & \multicolumn{2}{|c|}{$\begin{array}{c}\text { Base Case } \mathrm{PM}_{2.5} \\
\text { Concentration }\left(\mu \mathrm{g} \mathrm{m}^{-3}\right)\end{array}$} & \multicolumn{4}{|c|}{ Global 50\% BC Reduction } & \multicolumn{4}{|c|}{ Global $50 \%$ BC + OC Reduction } \\
\hline & $\begin{array}{l}\text { Simple } \\
\text { Average }\end{array}$ & $\begin{array}{r}\text { Population- } \\
\text { weighted } \\
\text { Average }\end{array}$ & $\begin{array}{r}\text { Simple } \\
\text { Average } \\
\Delta \mathrm{PM}_{2.5} \\
\left(\mathrm{ng} \mathrm{m}^{-3}\right)\end{array}$ & $\begin{array}{l}\text { Population- } \\
\text { weighted } \\
\Delta \mathrm{PM}_{2.5} \\
\left(\mathrm{ng} \mathrm{m}^{-3}\right)\end{array}$ & $\begin{array}{r}\text { Avoided } \\
\text { Deaths } \\
(\times 1000)\end{array}$ & $\begin{array}{r}\% \\
\mathrm{CP}\end{array}$ & $\begin{array}{r}\text { Simple } \\
\text { Average } \\
\Delta \mathrm{PM}_{2.5} \\
\left(\mathrm{ng} \mathrm{m}^{-3}\right)\end{array}$ & $\begin{array}{r}\text { Population- } \\
\text { weighted } \\
\Delta \mathrm{PM}_{2.5} \\
\left(\mathrm{ng} \mathrm{m}^{-3}\right)\end{array}$ & $\begin{array}{r}\text { Avoided } \\
\text { Deaths } \\
(\times 1000)\end{array}$ & $\begin{array}{r}\% \\
\mathrm{CP}\end{array}$ \\
\hline $\begin{array}{l}\text { North America } \\
\text { (NA) }\end{array}$ & 3.54 & 8.28 & 43 & 150 & $\begin{array}{r}4 \\
(3-5)\end{array}$ & 87.3 & 151 & 655 & $\begin{array}{r}14 \\
(11-18)\end{array}$ & 87.8 \\
\hline $\begin{array}{l}\text { South America } \\
\text { (SA) }\end{array}$ & 3.84 & 6.02 & 44 & 130 & $\begin{array}{r}1 \\
(1-2)\end{array}$ & 94.9 & 218 & 735 & $\begin{array}{r}8 \\
(6-9)\end{array}$ & 95.1 \\
\hline $\begin{array}{l}\text { Europe } \\
\text { (EU) }\end{array}$ & 9.77 & 13.4 & 147 & 230 & $\begin{array}{r}8 \\
(6-10)\end{array}$ & 91.1 & 772 & 1116 & $\begin{array}{r}41 \\
(31-51)\end{array}$ & 92.1 \\
\hline $\begin{array}{l}\text { Former Soviet } \\
\text { Union (FSU) }\end{array}$ & 5.87 & 12.29 & 60 & 177 & $\begin{array}{r}5 \\
(4-6)\end{array}$ & 96.1 & 466 & 1582 & $\begin{array}{r}45 \\
(34-55)\end{array}$ & 96.1 \\
\hline $\begin{array}{l}\text { Africa/Middle } \\
\text { East (AF/ME) }\end{array}$ & 5.32 & 7.21 & 64 & 126 & $\begin{array}{r}5 \\
(4-6)\end{array}$ & 97.4 & 454 & 941 & $\begin{array}{r}36 \\
(28-43)\end{array}$ & 97.5 \\
\hline $\begin{array}{l}\text { South Asia } \\
\text { (India; IN) }\end{array}$ & 19.28 & 36.29 & 420 & 732 & $\begin{array}{r}48 \\
(37-59)\end{array}$ & 96.7 & 3533 & 6409 & $\begin{array}{r}399 \\
(312-482)\end{array}$ & 96.7 \\
\hline $\begin{array}{l}\text { East Asia } \\
\text { (China; EA) }\end{array}$ & 27.98 & 70.17 & 453 & 1201 & $\begin{array}{r}81 \\
(61-100)\end{array}$ & 92.8 & 3483 & 9938 & $\begin{array}{r}622 \\
(480-755)\end{array}$ & 93.0 \\
\hline $\begin{array}{l}\text { Southeast Asia/ } \\
\text { Australia (SE/AU) }\end{array}$ & 4.81 & 9.55 & 54 & 247 & $\begin{array}{r}6 \\
(4-7)\end{array}$ & 94.2 & 361 & 1713 & $\begin{array}{r}40 \\
(31-49)\end{array}$ & 94.3 \\
\hline World & 2.75 & 29.7 & 33 & 542 & $\begin{array}{r}157 \\
(120-194)\end{array}$ & 94.1 & 221 & 4379 & $\begin{array}{r}1205 \\
(932-1463)\end{array}$ & 94.4 \\
\hline
\end{tabular}

inventory is more representative of $\mathrm{EC}$ than $\mathrm{BC}$, comparing modeled concentrations with EC is most appropriate (Vignati et al., 2010). For OC, we compare observations with simulated concentrations prior to conversion to $\mathrm{OM}$, and include SOA. We compare $\mathrm{SO}_{4}$ prior to mass conversion to ammonium sulfate. See the Supplement for comparisons of simulated monthly concentrations with IMPROVE and EMEP observations (Figs. S9 and S10).

Compared with observations from IMPROVE (average 2002-2003) for the US (Figs. 3 and S11), BC is generally simulated within a factor of two (inside the dashed lines), with some simulated concentrations higher than observations in the Northwest US, California, and Northeast US, and lower than observations in the South. Simulated OC is generally lower than observations, particularly in the Southeast, likely due to unrealistically low simulated SOA concentrations, consistent with previous studies using MOZART-4 (Dunlea et al., 2009; Emmons et al., 2010a). However, simulated OC is higher than observations in the Northwest US. Simulated $\mathrm{SO}_{4}$ generally matches observations in the Eastern US, but is higher than observations in the Western US (Fig. S12). Compared with observations from EMEP in Europe (average July 2002 to July 2003), simulated BC concentrations are lower than observations, particularly in Western Europe (Figs. 3 and S11). As for IMPROVE, simulated OC is lower than observations in Europe (Figs. 3 and S11) and sim- ulated $\mathrm{SO}_{4}$ is generally higher than observations (Fig. S12). For the few observations available from China and India, simulated concentrations are within a factor of two of observations in remote locations, but are often lower than observations in regional and urban locations (Figs. S13 and S14). Some of these discrepancies may be due to differences between volume averaged modeled concentrations in large grid cells and point measurements (Swall and Foley, 2009; Gilardoni et al., 2011), or the mismatch between 2006 measurements in Asia and 2002 simulated concentrations. Measurement methods may also cause overestimation of ambient EC concentrations (Fig. 3; Novakov et al., 2005), with the reflectance method for IMPROVE potentially measuring higher EC concentrations than the transmittance method used by EMEP (Chow et al., 2001).

Simulated simple (population-weighted) regional average surface $\mathrm{NO}_{3}$ concentrations range as high as 10.6 (30.6) $\mu \mathrm{g} \mathrm{m}^{-3}$ in EA and $6.3(15.1) \mu \mathrm{g} \mathrm{m}^{-3}$ in IN (Fig. 2 and Table S2). While a lack of global $\mathrm{NO}_{3}$ measurements limits our ability to evaluate simulated concentrations, these concentrations are consistent with those simulated by other global CTMs (e.g. Park et al., 2004). Any biases in simulated $\mathrm{NO}_{3}$ concentrations would not significantly affect our results, since $\mathrm{NO}_{3}$ varies little among the $\mathrm{BC}$ emission scenarios. 

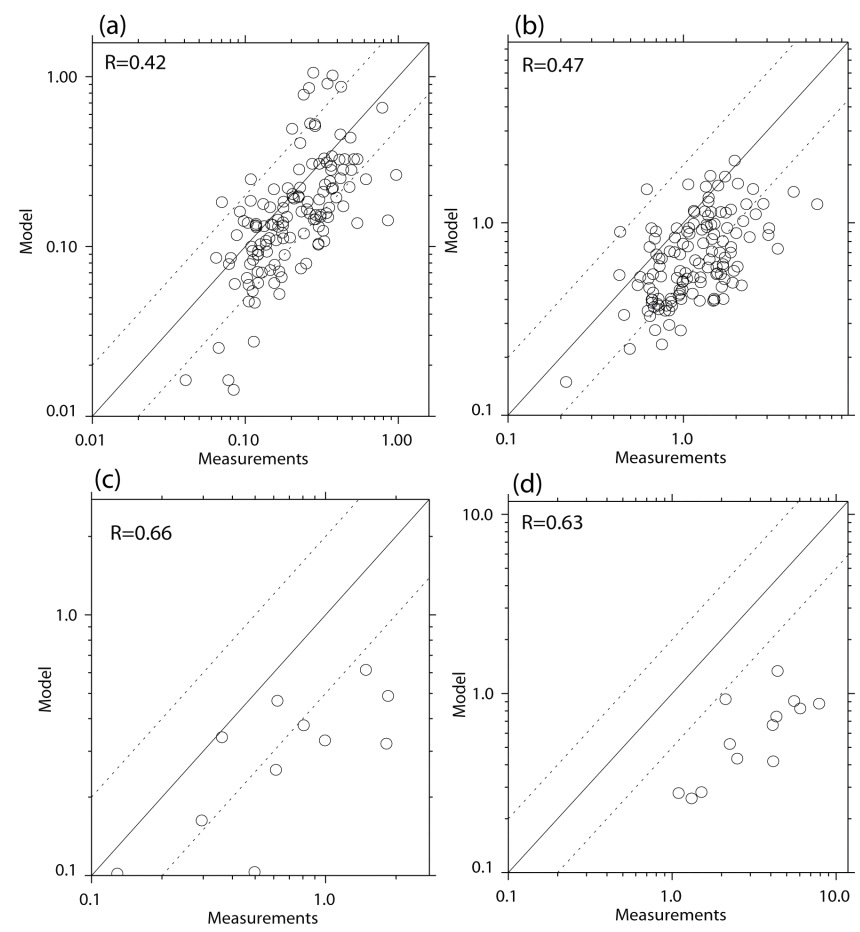

Fig. 3. Comparison of simulated annual average surface concentrations $\left(\mu \mathrm{g} \mathrm{m}^{-3}\right)$ with the IMPROVE surface monitoring network for remote locations in the United States (average of 2002 and 2003) for (a) BC and (b) OC (includes SOA), and with the EMEP surface monitoring network for Europe (average for July 2002 to June 2003) for (c) BC and (d) OC (includes SOA). Dashed lines represent the 1:2 and 2:1 lines indicating agreement within a factor of 2.

\subsection{Health impact function}

We calculate avoided premature deaths in each grid cell using the change in simulated $\mathrm{PM}_{2.5}$ concentration between the base case and the emission reduction scenario and a health impact function (HIF). Global CTMs have been used previously to estimate mortality due to total anthropogenic air pollution (Anenberg et al., 2010), long-range transport of air pollution (Duncan et al., 2008; Anenberg et al., 2009; Liu et al., 2009a; West et al., 2009), future changes in emissions (West et al., 2006, 2007; Selin et al., 2009), changes in one sector's emissions (Corbett et al., 2007; Barrett et al., 2010), fossil fuel and biofuel emissions (Jacobson, 2010), and air pollution changes associated with carbon dioxide emissions (Jacobson, 2008).

Here we use a log-linear relationship between long-term $\mathrm{PM}_{2.5}$ exposure and relative risk (RR), following Anenberg et al. (2010). RR $>1$ indicates that $\mathrm{PM}_{2.5}$ exposure increases risk of mortality. We use RR to calculate $\beta$, the concentration-response factor (CRF), and, as shown in Eq. (1), the attributable fraction (AF), the fraction of the disease burden attributable to the change in annual average $\mathrm{PM}_{2.5}(\Delta X)$. This HIF is applied in each grid cell by multi- plying the AF by the baseline mortality rate ( $\left.y_{0}\right)$ and exposed population (Pop), as shown in Eq. (2).

$\mathrm{AF}=(\mathrm{RR}-1) / \mathrm{RR}=1-\exp ^{-\beta \Delta X}$

$\Delta$ Mort $=y_{0}\left(1-\exp ^{-\beta \Delta X}\right)$ Pop

Some evidence suggests that air pollution mixtures with high $\mathrm{BC}$ fractions, "black smoke," "diesel $\mathrm{PM}_{2.5}$," and "traffic $\mathrm{PM}_{2.5}$," have stronger associations with mortality than other mixtures (Cooke et al., 2007; Brunekreef et al., 2009). Some studies that use ambient BC concentrations as a marker for air pollution mixtures also find stronger associations with mortality than those using total $\mathrm{PM}_{2.5}$ (Ostro et al., 2007, 2008; Bell et al., 2009; Peng et al., 2009; Smith et al., 2009). However, these studies are subject to large measurement and exposure error since $\mathrm{BC}$ is very spatially heterogeneous (Bell et al., 2011). Furthermore, many $\mathrm{PM}_{2.5}$ constituents are correlated, subjecting single-pollutant risk estimates to confounding by co-pollutants and often preventing definitive conclusions about their relative importance to risk (Smith et al., 2009). The body of evidence for differential risk of $\mathrm{PM}_{2.5}$ components, including $\mathrm{BC}$, is not as robust as for long-term $\mathrm{PM}_{2.5}$ (Smith et al., 2009; IEc, 2010). We therefore assume that all mixtures of $\mathrm{PM}_{2.5}$ are equally potent in causing premature mortality, and use the change in total $\mathrm{PM}_{2.5}$ in Eq. (2).

We calculate CRFs using estimates of RR of chronic mortality due to total $\mathrm{PM}_{2.5}$. The impacts of chronic $\mathrm{PM}_{2.5}$ exposure on mortality are established by a large body of epidemiology studies and include impacts of both short-term and long-term exposure. We use RR estimates from Krewski et al. (2009), the latest reanalysis of the American Cancer Society $\mathrm{PM}_{2.5}$ studies (e.g. Pope et al., 2002) and the largest among long-term $\mathrm{PM}_{2.5}$ mortality studies (e.g. Laden et al., 2006). For a $10 \mu \mathrm{g} \mathrm{m}^{-3}$ increase in $\mathrm{PM}_{2.5}$, RR was 1.06 (95\% CI, 1.04-1.08), 1.13 (95\% CI, 1.10-1.16), and 1.14 (95\% CI, 1.06-1.23) for total, cardiopulmonary, and lung cancer mortality in adults age 30+. These RRs were determined for the observed range of concentrations, 5.8 $22.2 \mu \mathrm{g} \mathrm{m}^{-3}$, and the linearity of the concentration-response relationship was also demonstrated up to $30 \mathrm{\mu g} \mathrm{m}^{-3}$ based on different years of $\mathrm{PM}_{2.5}$ data (1979-1983; Krewski et al., 2009). Causes of death differ globally from those in the US, and we estimate cardiopulmonary and lung cancer mortality, as they are more comparable around the world than all-cause mortality. We assume these CRFs apply globally, despite differences in health status, lifestyle, age structure, and medical care among global populations.

We use baseline cardiopulmonary and lung cancer mortality rates from the World Health Organization (WHO, 2004, 2008), population from the LandScan database (Oak Ridge National Laboratory, 2008) from 2006 (Fig. S15), and the fraction of the population age 30+ (WHO, 2004) to be consistent with Krewski et al. (2009), as described by Anenberg et al. (2010; see Table S3). 

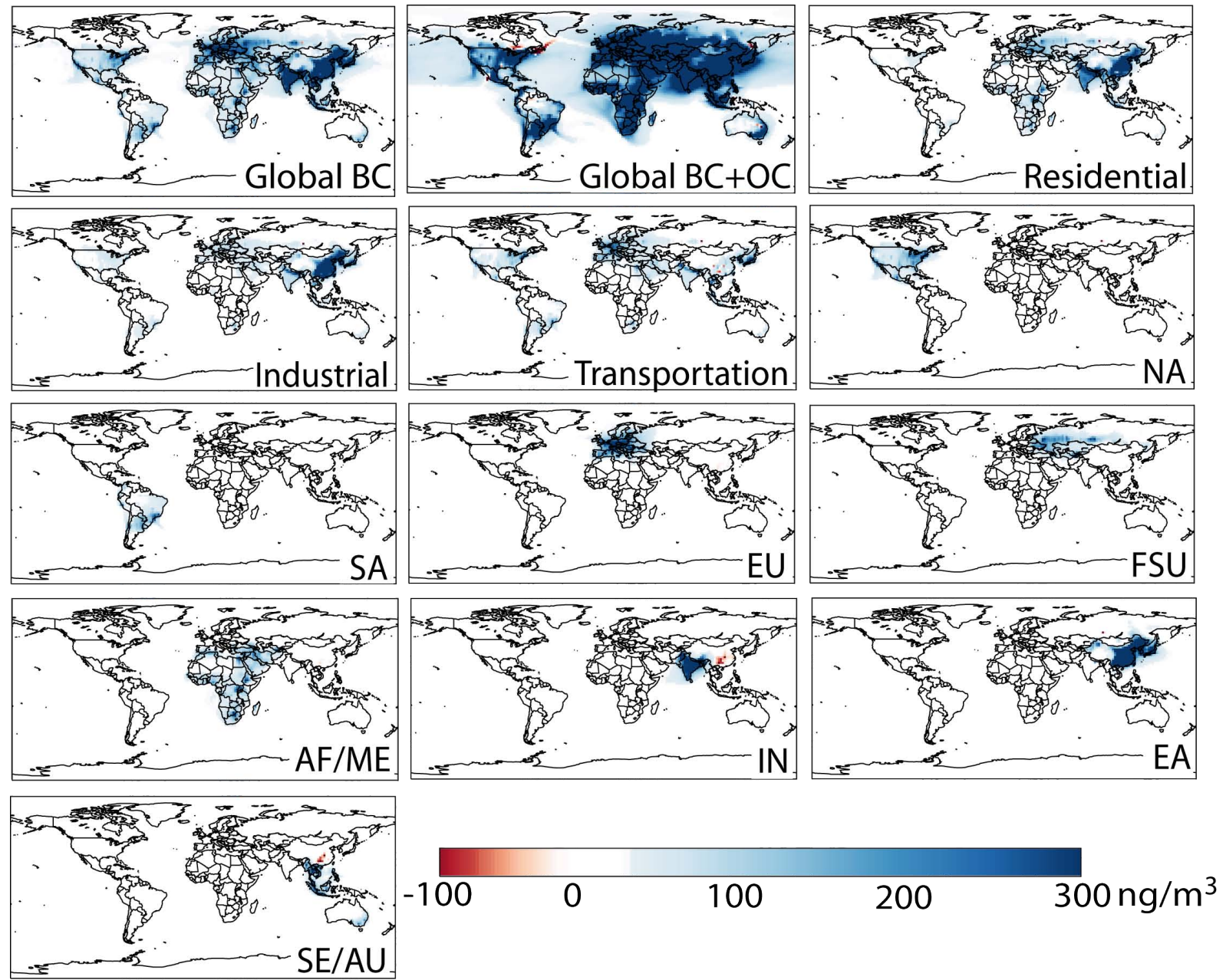

Fig. 4. Reduction in annual average surface $\mathrm{PM}_{2.5}$ concentration $\left(\mathrm{ng} \mathrm{m}^{-3}\right)$ for the global, sectoral, and regional emission reductions relative to the base case.

\section{Results}

\subsection{Global emission reductions}

Halving global anthropogenic $\mathrm{BC}$ emissions reduces the global annual average $\mathrm{PM}_{2.5}$ concentration by $33 \mathrm{ng} \mathrm{m}^{-3}$ $(1.2 \%)$, ranging among regions from $43 \mathrm{ng} \mathrm{m}^{-3}$ in NA to $453 \mathrm{ng} \mathrm{m}^{-3}$ in EA (Table 1 and Fig. 4). Population-weighted average $\mathrm{PM}_{2.5}$ concentrations decrease by $542 \mathrm{ng} \mathrm{m}^{-3}$ $(1.8 \%)$ globally, ranging from $126 \mathrm{ng} \mathrm{m}^{-3}$ in $\mathrm{AF} / \mathrm{ME}$ to $1201 \mathrm{ng} \mathrm{m}^{-3}$ in EA. Regional BC concentrations decrease by $25-49 \%$, with smaller percentage reductions in regions with frequent wildfires (e.g. SA, AF/ME, SE/AU; Figs. 5a and S16). Wildfires are assumed to be natural and are therefore excluded from the emission reduction. We estimate that these $\mathrm{PM}_{2.5}$ reductions would avoid $\sim 157000(95 \% \mathrm{CI}$, 120000-194000) annual premature deaths worldwide (Table 1$)$, over $80 \%$ of which occur in EA $(81000,95 \%$ CI, $61000-100000)$ and IN (48 000, $95 \%$ CI, $37000-59000$;
Fig. 6). These regions have large emissions and exposed populations, and IN also has high baseline cardiopulmonary mortality rates. In all regions except NA which has a relatively high baseline lung cancer mortality rate, $>90 \%$ of avoided deaths are from cardiopulmonary disease.

Estimated reductions in $\mathrm{PM}_{2.5}$ concentrations are generally smaller than reductions in $\mathrm{BC}$ concentrations due to increased $\mathrm{SO}_{4}$ production (Fig. 5a). Aerosols affect gas-phase chemistry by absorbing or scattering radiation that drives photochemistry (He and Carmichael, 1999; Liao et al., 1999; Castro et al., 2001). Previous studies using regional models (Jacobson, 1998; Li et al., 2005) and global models (Martin et al., 2003), including using the aerosol scheme used in MOZART-4 specifically (Tie et al., 2005), find that high BC concentrations lead to reduced photolysis rates for $\mathrm{O}_{3}$ and nitrogen dioxide and, therefore, reduced $\mathrm{O}_{3}$ concentrations. Here, we find that reduced $\mathrm{BC}$ concentration increases photolysis and leads to increased concentrations of $\mathrm{O}_{3}$, hydroxyl radical $(\mathrm{OH})$, and hydrogen peroxide $\left(\mathrm{H}_{2} \mathrm{O}_{2}\right)$, as shown in 

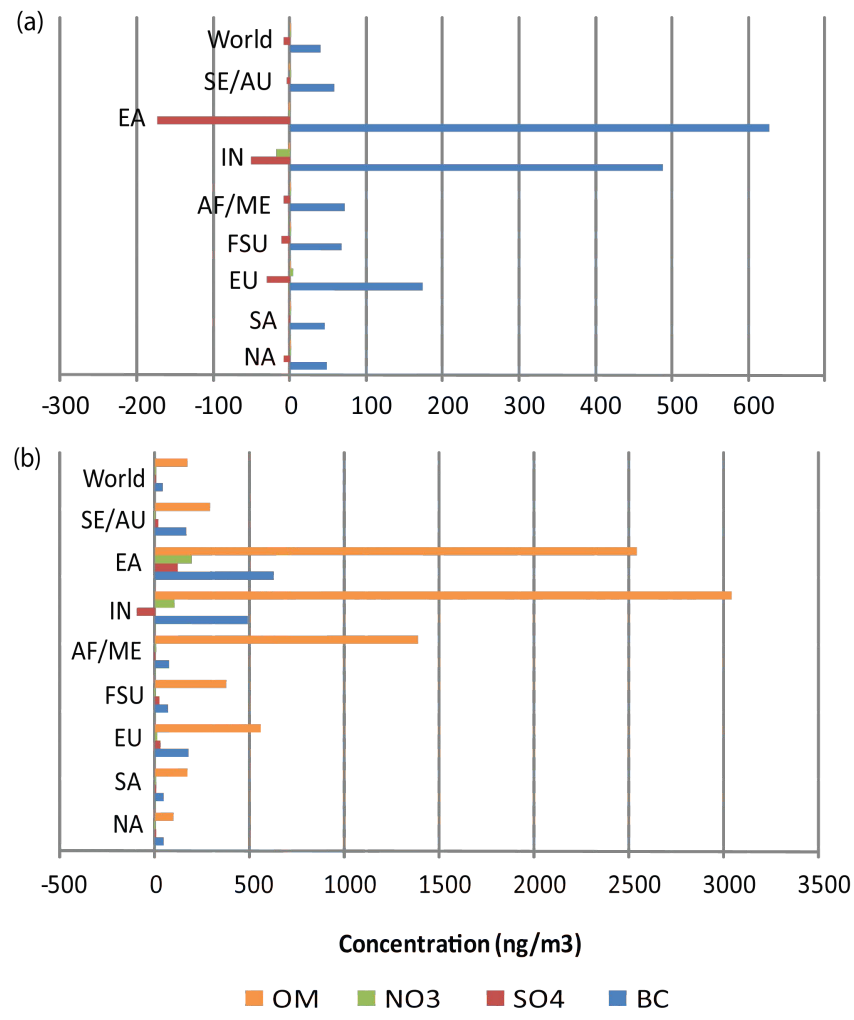

Fig. 5. Reduction in global and regional annual average concentrations $\left(\mathrm{ng} \mathrm{m}^{-3}\right)$ of $\mathrm{PM}_{2.5}$ species for halving global anthropogenic (a) $\mathrm{BC}$ emissions and (b) $\mathrm{BC}+\mathrm{OC}$ emissions, relative to the base case. Negative values indicate increases.

Fig. S17. As described by Tie et al. (2001), gas-phase production of $\mathrm{SO}_{4}$ in MOZART-4 occurs via R1, while aqueous phase (in-cloud) production occurs via Reactions (R2) and (R3), where $\mathrm{S}(\mathrm{IV})$ is total dissolved sulfur $\left(\mathrm{HSO}_{3}\right.$ and $\left.\mathrm{SO}_{3}\right)$.

$\mathrm{SO}_{2}+\mathrm{OH} \rightarrow \mathrm{SO}_{4}$

$\mathrm{S}(\mathrm{IV})+\mathrm{O}_{3} \rightarrow \mathrm{SO}_{4}+$ products

$\mathrm{S}(\mathrm{IV})+\mathrm{H}_{2} \mathrm{O}_{2} \rightarrow \mathrm{SO}_{4}+$ products

Through these reactions, increased concentrations of $\mathrm{OH}$ (global annual mean increase of $0.34 \%), \mathrm{O}_{3}(0.03 \%)$, and $\mathrm{H}_{2} \mathrm{O}_{2}(0.12 \%)$ in response to $\mathrm{BC}$ emission reductions lead to enhanced $\mathrm{SO}_{4}$ production $(0.13 \%)$. The resulting $\mathrm{SO}_{4}$ increases are very small percentages of total $\mathrm{PM}_{2.5}$ (up to $0.7 \%$ regional average in EA; Fig. S16) but since $\mathrm{SO}_{4}$ concentrations are much larger than $\mathrm{BC}$ concentrations, they can offset up to $28 \%$ (in EA) of regional $\mathrm{BC}$ reductions (Fig. 5a). $\mathrm{NO}_{3}$ and SOA concentrations are also formed in the atmosphere by reaction with photochemical oxidants. We find changes in regional annual average $\mathrm{NO}_{3}$ concentrations up to $20 \mathrm{ng} \mathrm{m}^{-3}$
$(0.3 \%)$ as a result of the $\mathrm{BC}$ emission reduction, but no appreciable change in SOA. We include changes to all $\mathrm{PM}_{2.5}$ species in our mortality calculation, but do not include $\mathrm{O}_{3}$ increases.

Halving global anthropogenic $\mathrm{BC}$ and $\mathrm{OC}$ emissions together reduces $\mathrm{BC}$ concentrations by the same amount as halving $\mathrm{BC}$ emissions alone, but $\mathrm{OM}$ is also reduced (Fig. $5 b$ ), such that annual average $\mathrm{PM}_{2.5}$ reductions are larger by a factor of four in NA to over eight in IN (Table 1). These $\mathrm{PM}_{2.5}$ reductions are associated with $\sim 8$ times more (1.2, $95 \%$ CI, 0.9-1.5 million) global premature deaths than is estimated for halving $\mathrm{BC}$ alone (Table 1). Here, changes in radiation absorption by $\mathrm{BC}$ and scattering by $\mathrm{OM}$, which can increase the pathlength of solar radiation and accelerate photochemistry (e.g. Dickerson et al., 1997), have opposing effects on gas-phase chemistry. We find increases in $\mathrm{OH}$ (global annual mean increase of $0.81 \%$ ) and $\mathrm{O}_{3}(0.44 \%)$ concentrations but decreases in $\mathrm{H}_{2} \mathrm{O}_{2}$ concentrations $(-0.34 \%)$, resulting in mixed effects on $\mathrm{SO}_{4}(-0.07 \%$ globally; Fig. S18). We also find mixed directional changes in $\mathrm{NO}_{3}$ (regional increase up to $200 \mathrm{ng} \mathrm{m}^{-3}, 2.0 \%$ ) and SOA (up to $47 \mathrm{ng} \mathrm{m}^{-3}, 55 \%$ ) that do not necessarily follow the directional change in $\mathrm{SO}_{4}$ (Fig. 5b).

Estimated avoided deaths from halving anthropogenic $\mathrm{BC}$ and $\mathrm{BC}+\mathrm{OC}$ are consistent with estimates by Anenberg et al. (2010) of the global burden of anthropogenic $\mathrm{PM}_{2.5}$ on mortality ( $\sim 3.7$ million deaths) when multiplied by the fraction of $\mathrm{PM}_{2.5}$ that is $\mathrm{BC}(9 \%, 300000$ deaths $)$ and $\mathrm{OM}$ (46\%, 1.7 million deaths) in that study. The global burden estimate is twice our estimated deaths from halving $\mathrm{BC}$, but only 1.6 times those from halving $\mathrm{OC}$ (1.2 million from halving $\mathrm{BC}+\mathrm{OC}$ minus 0.2 million from halving $\mathrm{BC}$ alone). While both studies use the MOZART model, we use here an updated version, MOZART-4, which includes aerosol chemistry and interactions with radiation. Our methodology also differs for $\mathrm{BC}$ and $\mathrm{OC}$ emissions, assumptions for converting $\mathrm{OC}$ to $\mathrm{OM}$, and years of emissions and meteorology.

\subsection{Regional BC emission reductions}

We now examine the surface $\mathrm{PM}_{2.5}$ and mortality impacts of halving anthropogenic emissions in eight world regions individually. EA contributes $32 \%$ of global anthropogenic $\mathrm{BC}$ emissions, more than double the contribution from any other region (Fig. 1). AF/ME and IN follow, with $13 \%$ and $12 \%$.

We find the greatest reductions in population-weighted $\mathrm{PM}_{2.5}$ occur within the EA $\left(1262 \mathrm{ng} \mathrm{m}^{-3}\right)$ and IN (733 $\mathrm{ng} \mathrm{m}^{-3}$ ) source regions, due to high emissions (Table 2). For all regions, the contribution of $\mathrm{BC}$ emissions from other regions to surface $\mathrm{PM}_{2.5}$ concentrations is very small, although some transport occurs between FSU, AF/ME, and $\mathrm{EU}$, which are close in proximity. For some regions, halving $\mathrm{BC}$ emissions leads to small increases in $\mathrm{OH}, \mathrm{O}_{3}$, and $\mathrm{H}_{2} \mathrm{O}_{2}$ in distant regions, which enhance $\mathrm{SO}_{4}$ production where $\mathrm{SO}_{2}$ 

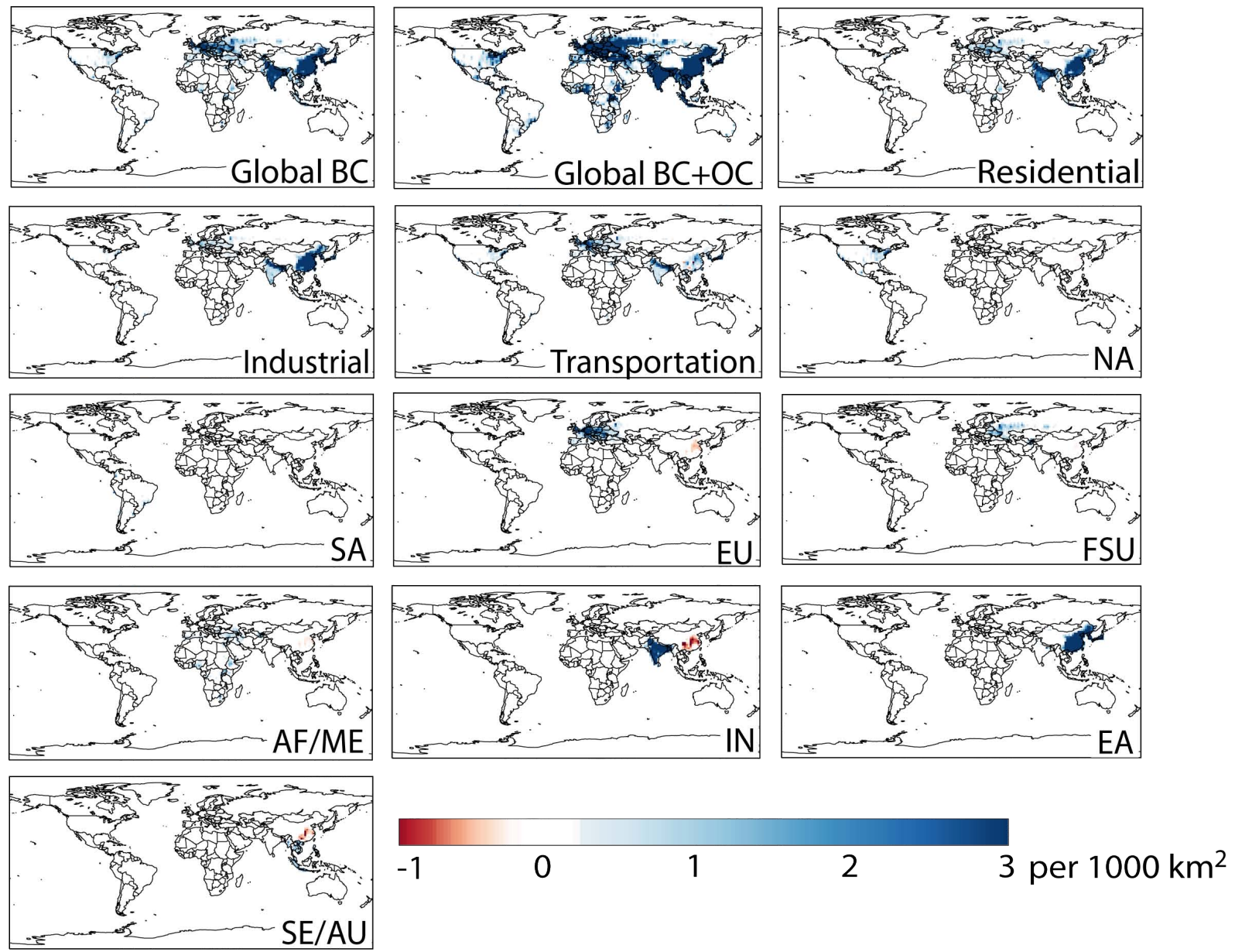

Fig. 6. Avoided annual cardiopulmonary and lung cancer deaths per $1000 \mathrm{~km}^{2}$, for the global, sectoral, and regional emission reductions relative to the base case.

emissions are high, such as in EA (Figs. S19 and S20). Since $\mathrm{BC}$ concentrations are not greatly impacted outside of the source region, small $\mathrm{SO}_{4}$ increases in distant regions can lead to overall $\mathrm{PM}_{2.5}$ increases (Table 2). For example, halving $\mathrm{BC}$ emissions in IN increases population-weighted average $\mathrm{PM}_{2.5}$ by $20 \mathrm{ng} \mathrm{m}^{-3}$ in EA. The limited influence of extra-regional $\mathrm{BC}$ emissions on regional surface $\mathrm{PM}_{2.5}$ concentrations is consistent with other studies finding that BC comprises $0-3 \%$ of background surface aerosol concentrations (Liu et al., 2009b) and that foreign BC emissions contribute $0-5 \%$ of regional surface $\mathrm{BC}$ concentrations (TF HTAP, 2010).

Halving BC emissions in EA avoids $85000(95 \%$ CI, 64000-105000) annual premature deaths globally, more than any other region, followed by IN with 47000 (95\% CI, 36000-58 000; Table 2). EA and IN contribute $53 \%$ and $31 \%$ to all avoided deaths from halving global BC emissions, 1.6 and 2.5 times greater than their contributions to global anthropogenic $\mathrm{BC}$ emissions, owing to large populations in both regions and high cardiopulmonary mortality rates in IN
(Table S3). The small $\mathrm{SO}_{4}$ increases in distant regions resulting from some regional $\mathrm{BC}$ emission reductions have very little impact on mortality. To compare mortality impacts of $\mathrm{BC}$ emissions across regions, we calculate the mortality impacts per unit BC emissions reduced (Fig. 7). Per unit emission, the mortality impact of $\mathrm{BC}$ emissions is largest for IN (136 premature deaths avoided per $\mathrm{Gg} \mathrm{BC}$ emitted), followed by EA (90). Reducing BC emissions in IN is more effective at reducing within-region $\mathrm{PM}_{2.5}\left(2.1 \mathrm{ng} \mathrm{m}^{-3} \mathrm{PM}_{2.5}\right.$ reduction per unit BC emission reduced in IN versus 1.3 in EA; Fig. 1 and Table 2). IN also has higher baseline cardiopulmonary mortality rates (Table S3).

\subsection{Sectoral BC emission reductions}

We next examine the impacts of halving global $\mathrm{BC}$ emissions from each major economic sector individually. Globally, $93 \%$ of anthropogenic BC emissions are estimated to be from three sectors: residential ( $38 \%)$, industrial (includes non-road transportation; $29 \%$ ), and transportation (on-road 
Table 2. Reduction in population-weighted average $\mathrm{PM}_{2.5}$ concentration (first row for each receptor region, $\mathrm{ng} \mathrm{m}^{-3}$ ) and annual avoided premature cardiopulmonary and lung cancer deaths (second row, thousands) in each receptor region after halving anthropogenic BC emissions in each source region. Confidence intervals (95\%, in parentheses) reflect uncertainty in the CRF only.

\begin{tabular}{|c|c|c|c|c|c|c|c|c|}
\hline \multirow[b]{2}{*}{$\begin{array}{l}\text { Receptor } \\
\text { Region }\end{array}$} & \multicolumn{8}{|c|}{ Source Region } \\
\hline & NA & SA & EU & FSU & $\mathrm{AF} / \mathrm{ME}$ & IN & EA & $\mathrm{SE} / \mathrm{AU}$ \\
\hline \multirow[t]{2}{*}{ NA } & 151 & -1 & -1 & -1 & -1 & -1 & -2 & -1 \\
\hline & $4(3-5)$ & 0 & 0 & 0 & 0 & 0 & 0 & 0 \\
\hline \multirow[t]{2}{*}{ SA } & 0 & 129 & 0 & 0 & 0 & 0 & 0 & 0 \\
\hline & 0 & $1(1-2)$ & 0 & 0 & 0 & 0 & 0 & 0 \\
\hline \multirow[t]{2}{*}{ EU } & 0 & 0 & 225 & 5 & 9 & -1 & -3 & 10 \\
\hline & 0 & 0 & $8(6-10)$ & 0 & 0 & 0 & 0 & 0 \\
\hline \multirow[t]{2}{*}{ FSU } & -1 & 0 & 39 & 135 & 23 & -1 & 1 & 0 \\
\hline & 0 & 0 & $1(1-1)$ & $4(3-5)$ & 0 & 0 & 0 & 0 \\
\hline \multirow[t]{2}{*}{$\mathrm{AF} / \mathrm{ME}$} & 0 & 0 & 7 & 5 & 116 & 1 & 0 & 0 \\
\hline & 0 & 0 & 0 & 0 & $4(3-5)$ & 0 & 0 & 0 \\
\hline \multirow[t]{2}{*}{ IN } & -1 & -1 & -1 & -1 & 0 & 733 & 4 & 0 \\
\hline & 0 & 0 & 0 & 0 & 0 & $49(37-59)$ & 0 & 0 \\
\hline \multirow[t]{2}{*}{ EA } & -4 & 0 & -9 & -3 & -6 & -20 & 1262 & -9 \\
\hline & 0 & 0 & $-1(-1--1)$ & 0 & $-1(0--1)$ & $-2(-1--2)$ & 85 (64-105) & $-1(-1--1)$ \\
\hline \multirow[t]{2}{*}{ SE/AU } & 0 & 0 & 0 & 0 & 1 & 8 & 9 & 230 \\
\hline & 0 & 0 & 0 & 0 & 0 & 0 & 0 & $5(4-7)$ \\
\hline
\end{tabular}

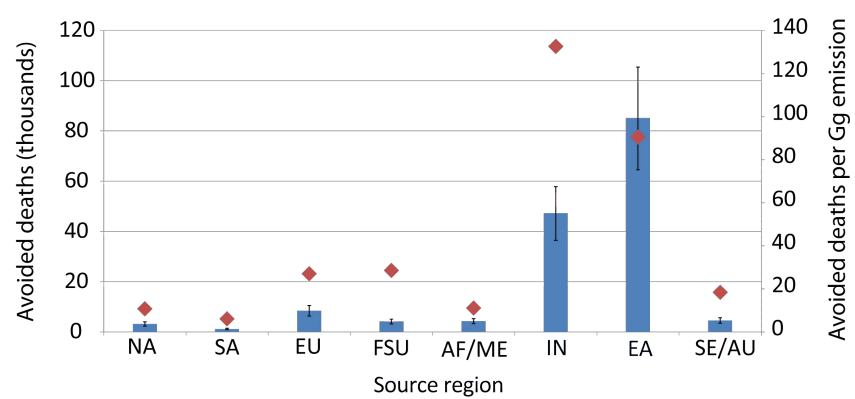

Fig. 7. Global annual avoided premature cardiopulmonary and lung cancer deaths (thousands; blue bars) and avoided premature deaths per Gg BC emissions reduced (red diamonds), for halving anthropogenic $\mathrm{BC}$ emissions in each source region relative to the base case. Confidence intervals $(95 \%)$ reflect uncertainty in the CRF only.

only; 26\%) (Fig. 1). Each sector's contribution to total anthropogenic BC emissions differs considerably by region, with transportation emissions estimated to contribute most in developed regions ( $55 \%$ in NA and $53 \%$ in EU), and the residential sector contributing most in developing regions $(62 \%$ in IN and $56 \%$ in both AF/ME and FSU). In EA, $50 \%$ and $35 \%$ are from the industrial and residential sectors.

Globally, halving residential BC emissions impacts population-weighted average $\mathrm{PM}_{2.5}$ and mortality most, with $250 \mathrm{ng} \mathrm{m}^{-3} \mathrm{PM}_{2.5}$ reduced and 74000 (95\% CI, 57000
91000 ) annual avoided deaths (Table 3). Avoided deaths are likely underestimated for the residential sector since we exclude changes in indoor exposure. The global mortality impacts of reducing industrial $\mathrm{BC}$ emissions are also large, while those from reducing transportation emissions are fewer. Halving residential, industrial, and transportation emissions contributes $47 \%, 35 \%$, and $15 \%$ to the avoided deaths from halving all anthropogenic BC emissions. These contributions are 1.2, 1.2, and 0.6 times each sector's portion of global BC emissions, owing to the degree of co-location with population globally. As for $\mathrm{BC}$ emissions, the relative magnitude of each sector's impact differs substantially in developed versus developing regions. For example, in IN, residential, industrial, and transportation emissions contribute $66 \%, 18 \%$, and $14 \%$ of the $\mathrm{PM}_{2.5}$ decrease, while in NA these sectors contribute $15 \%, 20 \%$, and $60 \%$. Of the total avoided deaths from halving global anthropogenic BC emissions, $26 \%$ occur in EA from the industrial sector, and $20 \%$ occur in each of IN and EA from the residential sector.

The mortality impact per unit BC emitted ("mitigation efficiency") in each region is similar regardless of the sector from which emissions were reduced (Fig. 8) and follows the same ranking as for the regional reductions (Fig. 7). However, reducing $\mathrm{BC}$ emissions from the transportation sector in EA has a smaller per unit impact on mortality relative to the residential and industrial sectors. While the industrial and residential sectors in EA have the greatest BC emissions ("mitigation potential"), all three sectors in IN have the greatest overall mitigation efficiency. Outside of IN and EA, 
Table 3. Population-weighted reduction in annual average $\mathrm{PM}_{2.5}\left(\mathrm{ng} \mathrm{m}^{-3}\right)$ and annual avoided premature cardiopulmonary and lung cancer deaths (in thousands) for halving global BC emissions from each sector, relative to the base case. Confidence intervals (95\%, in parentheses) reflect uncertainty in the CRF only.

\begin{tabular}{|c|c|c|c|c|c|c|}
\hline \multirow[b]{2}{*}{$\begin{array}{l}\text { Receptor } \\
\text { region }\end{array}$} & \multicolumn{2}{|c|}{ Residential } & \multicolumn{2}{|c|}{ Industrial } & \multicolumn{2}{|c|}{ Transportation } \\
\hline & $\begin{array}{r}\text { Population- } \\
\text { weighted } \\
\Delta \mathrm{PM}_{2.5} \\
\left(\mathrm{ng} \mathrm{m}^{-3}\right)\end{array}$ & $\begin{array}{r}\text { Avoided } \\
\text { deaths } \\
\times 1000\end{array}$ & $\begin{array}{r}\text { Population- } \\
\text { weighted } \\
\Delta \mathrm{PM}_{2.5} \\
\left(\mathrm{ng} \mathrm{m}^{-3}\right)\end{array}$ & $\begin{array}{r}\text { Avoided } \\
\text { deaths } \\
\times 1000\end{array}$ & $\begin{array}{r}\text { Population- } \\
\text { weighted } \\
\Delta \mathrm{PM}_{2.5} \\
\left(\mathrm{ng} \mathrm{m}^{-3}\right)\end{array}$ & $\begin{array}{r}\text { Avoided } \\
\text { deaths } \\
\times 1000\end{array}$ \\
\hline NA & 22 & $1(0-1)$ & 29 & $1(1-1)$ & 88 & $2(2-3)$ \\
\hline SA & 28 & $0(0-0)$ & 30 & $0(0-0)$ & 65 & $1(0-1)$ \\
\hline EU & 50 & $2(1-2)$ & 42 & $1(1-2)$ & 124 & $4(3-5)$ \\
\hline FSU & 99 & $3(2-3)$ & 32 & $1(1-1)$ & 33 & $1(1-1)$ \\
\hline $\mathrm{AF} / \mathrm{ME}$ & 65 & $2(2-3)$ & 21 & $1(1-1)$ & 31 & $1(1-1)$ \\
\hline IN & 480 & $32(25-39)$ & 135 & $9(7-11)$ & 105 & $7(5-9)$ \\
\hline EA & 461 & $32(24-39)$ & 602 & $41(31-50)$ & 89 & $5(4-7)$ \\
\hline SE/AU & 115 & $3(2-3)$ & 50 & $1(1-1)$ & 71 & $2(1-2)$ \\
\hline World & 250 & $74(57-91)$ & 191 & $55(42-68)$ & 80 & $23(17-28)$ \\
\hline
\end{tabular}

imitigation efficiency is greatest for FSU, SE/AU, and EU, while mitigation potential is greatest for the residential sector in $\mathrm{AF} / \mathrm{ME}$ and the transportation sector in EU and NA.

\section{Sensitivity of results to concentration-response factors}

For the results presented above, we assume that the CRFs estimated for the US apply globally, although simulated concentrations in some grid cells in Asia are much higher than the range included in the ACS study (Table S3). Current evidence does not support the existence of low or high thresholds beyond which changes in $\mathrm{PM}_{2.5}$ concentration have no impact on mortality (Krewski et al., 2009). However, while no long-term epidemiology studies have examined the relationship between $\mathrm{PM}_{2.5}$ concentration and mortality at higher concentrations, the per-unit impact of $\mathrm{PM}_{2.5}$ on mortality may be smaller at higher concentrations (Pope et al., 2009; Smith and Peel, 2010). Without quantitative evidence describing the concentration-response relationship at a wide range of concentrations, we examine the effect of low and high health effect thresholds on estimated deaths.

For the case where BC emissions are halved globally, applying a high-concentration threshold of $50 \mathrm{\mu g} \mathrm{m}^{-3}$ (an assumption consistent with previous studies, e.g. Cohen et al., 2004) reduces global avoided deaths by $56 \%$ compared to no threshold. Over $99 \%$ of the difference in estimated deaths occurs in EA and IN (Fig. 9) where concentrations most frequently exceed the threshold, but the majority $(60 \%)$ of estimated avoided deaths still occur in these regions. Applying a low-concentration threshold of $5.8 \mathrm{\mu g} \mathrm{m}^{-3}$, the lowest measured level in Krewski et al. (2009), reduces global avoided deaths by $2.1 \%, 33 \%$ and $22 \%$ of which occur in AF/ME and SE/AU.

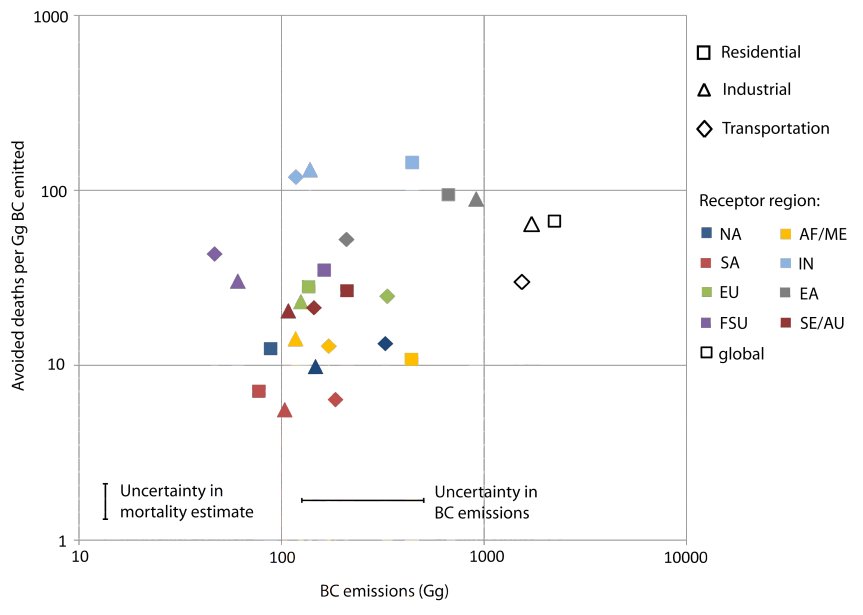

Fig. 8. Annual avoided premature cardiopulmonary and lung cancer deaths per unit $\mathrm{BC}$ emissions reduced vs. total $\mathrm{BC}$ emissions $(\mathrm{Gg})$ for particular source sectors within each region. Avoided deaths are estimated in the three simulations where global emissions in each sector are halved, and shown for each receptor region; these deaths are compared with emissions from each region, assuming that deaths from inter-regional transport are negligible (Table 2). Uncertainty in the mortality estimates is a factor of 0.23 from the central estimate, which includes uncertainties in the cardiopulmonary and lung cancer CRFs only. Uncertainty in BC emissions is assumed to be a factor of 2 from the central estimate (Bond et al., 2004, 2007). Since these uncertainties are factor differences from the central estimate, they are identical for each data point.

We also examine the effect of applying the significantly higher CRFs from the latest reanalaysis of the Harvard Six Cities cohort study (Laden et al., 2006) which found that for a $10 \mu \mathrm{g} \mathrm{m}^{-3}$ increase in $\mathrm{PM}_{2.5}$, RRs of cardiovascular and lung cancer mortality were 1.28 (95\% CI, 1.13-1.44) 


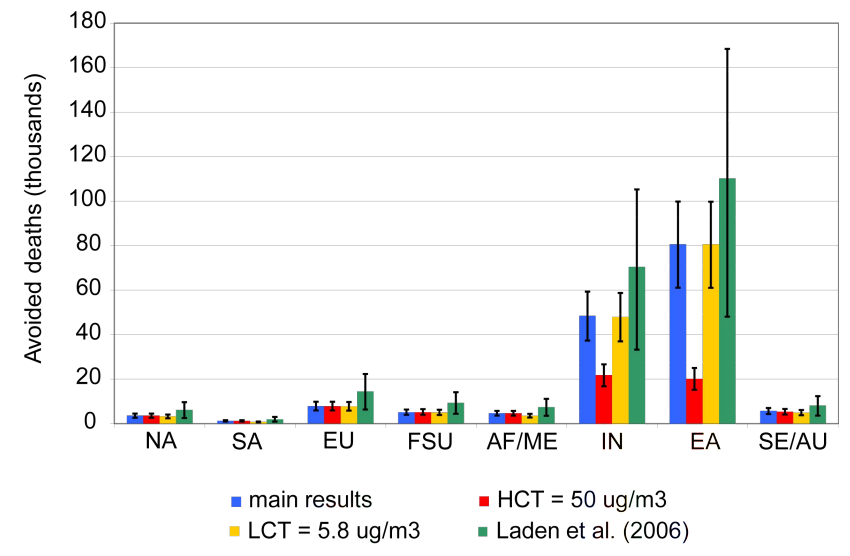

Fig. 9. Sensitivity of estimated avoided annual premature cardiopulmonary and lung cancer deaths from halving global anthropogenic BC emissions to a high concentration threshold (HCT) of $50 \mu \mathrm{g} \mathrm{m}^{-3}$, a low-concentration threshold (LCT) of $30 \mu \mathrm{g} \mathrm{m}^{-3}$, and relative risk estimates from Laden et al. (2006; cardiovascular and lung cancer mortality only). Confidence intervals (95\%) reflect uncertainty in the CRF only.

and 1.27 (95\% CI, 0.96-1.69). Consistent with the relative magnitudes of the RR estimates, using the RRs from Laden et al. (2006) increases estimated global avoided deaths by $45.1 \%$, which is distributed around the world.

\section{Uncertainties}

While we quantify uncertainty for mortality impacts from statistical error in the CRF, we are unable to quantify several other important uncertainties. Uncertainty in global BC emission inventories is estimated to be about a factor of 2 , and could be comparatively larger for the residential and industrial sectors in developing regions, where emissions are more difficult to estimate (Bond et al., 2004, 2007). Global anthropogenic $\mathrm{BC}$ emissions are also generally allocated to grid cells according to population, an assumption that may be more accurate for some regions and sectors than others. Simulated BC concentrations vary widely among global CTMs due to differing assumptions for emissions and parameterization of aerosol processes, such as aging and wet and dry deposition rates (Koch et al., 2009; Vignati et al., 2010). Underestimation of deposition fluxes would cause overestimation of $\mathrm{PM}_{2.5}$ concentration and mortality impacts, and vice versa. While we include feedback of aerosols on photolysis rates, we exclude the impacts of aerosols on meteorology, including on the atmospheric lapse rate, which would affect circulation, and cloud condensation nuclei, which would affect aerosol wet deposition rates. These model variations may affect estimated mortality impacts more than uncertainty in the CRF, as has been shown for ozone (Anenberg et al., 2009). The coarse grid resolution of the global CTM also contributes to uncertainty, since it does not capture fine spatial gradients of concentrations, particularly around urban areas. As BC and the primary component of OM are directly emitted, this uncertainty may be particularly important for this study. We found that BC and OC concentrations are generally lower than observations in the US and Europe and for the few available observations in China and India, likely causing our calculated impacts of halving emissions to be underestimates.

Several uncertainties are also associated with health impact function parameters. We assume that all $\mathrm{PM}_{2.5}$ mixtures are equally toxic, despite substantial compositional variation around the world and some evidence suggesting that BCcontaining mixtures may be more toxic than the average. Additional research is needed to identify differential toxicity of air pollutant mixtures (e.g. Smith et al., 2009; Dominici et al., 2010; Vedal and Kaufman, 2011). We also assume that CRFs found in the US apply globally, despite differences in concentration levels, populations, lifestyle, age structure, and medical care. This assumption is supported by evidence suggesting that $\mathrm{PM}_{2.5}$-mortality associations are similar among different sub-populations in the US (Pope et al., 2009), though different sub-populations around the world likely have larger differences than those in the US, and by similar findings among short-term $\mathrm{PM}_{2.5}$ mortality studies around the world (HEI, 2010; Atkinson et al., 2011). We emphasize cause-specific mortality which may be more comparable around the world than all-cause mortality, but may result in underestimates of the total mortality impacts since other causes of death are likely also associated with $\mathrm{PM}_{2.5}$.

\section{Conclusions}

We have estimated the impacts of global, regional, and sectoral $\mathrm{BC}$ emission reductions on surface air quality and human mortality using a global chemical transport model (CTM) to simulate $\mathrm{PM}_{2.5}$ concentrations and a health impact function to calculate mortality changes. We find that halving global anthropogenic BC emissions would reduce global population-weighted average $\mathrm{PM}_{2.5}$ by $542 \mathrm{ng} \mathrm{m}^{-3}(1.8 \%)$ and avoid 157000 (95\% confidence interval, 120000194 000) annual premature deaths worldwide, corresponding to $4 \%$ of $\mathrm{PM}_{2.5}$-related deaths (Anenberg et al., 2010) and $0.3 \%$ of all deaths. Since the chemical and physical processes governing BC concentrations in MOZART-4 and our health impact function are approximately linear, these results can be scaled to estimate the surface air quality and health impacts of larger or smaller changes in BC emissions. We exclude the likely substantial morbidity benefits of reducing $\mathrm{BC}$ due to lack of data on baseline morbidity rates. Morbidity impacts may not be directly proportional to mortality impacts because of differences in hospitalization rates and medical care around the world. 
The vast majority of surface $\mathrm{PM}_{2.5}$ and health benefits from $\mathrm{BC}$ emission reductions occur within the source region. Some inter-regional transport occurs between FSU, AF/ME, and $\mathrm{EU}$, which are close in proximity. Regional definitions used here are very broad, encompassing many countries, which obscures smaller-scale transport of pollution across political boundaries. While most of the avoided deaths from halving global anthropogenic $\mathrm{BC}$ can be achieved by halving EA emissions (54\%), followed by IN emissions ( $31 \%)$, IN emissions have $50 \%$ greater mortality impacts per unit BC emitted than EA emissions.

Globally, the contribution of residential, industrial, and transportation $\mathrm{BC}$ emissions to $\mathrm{PM}_{2.5}$-related mortality is $1.2,1.2$, and 0.6 times each sector's contribution to anthropogenic $\mathrm{BC}$ emissions, owing to the degree of co-location between that sector's emissions and global population. Within each region, mortality per unit emission varies little by source sector; however, impacts of residential $\mathrm{BC}$ emissions are underestimates since impacts due to indoor $\mathrm{PM}_{2.5}$ exposure are excluded. The underestimation is likely most pronounced in areas of South Asia, East Asia, and Africa that rely on solid fuel combustion for cooking and heating (Smith et al., 2004). In addition, the coarse grid resolution used here does not capture the spatial scale at which actual exposure to emissions from these sectors occurs (e.g. near roadways for the transportation sector). These results should be further studied at finer resolutions to better simulate actual exposure.

We find that reducing $\mathrm{BC}$ emissions increases regional $\mathrm{SO}_{4}$ concentrations up to $28 \%$ of regional $\mathrm{BC}$ concentration reductions due to reduced absorption of radiation that drives photochemistry. The $\mathrm{SO}_{4}$ increase lessens the health benefits of $\mathrm{BC}$ reductions, which are calculated based on total $\mathrm{PM}_{2.5}$ concentrations, but may enhance the climate benefit since $\mathrm{SO}_{4}$ scatters radiation. We estimate $\sim 8$ times more avoided deaths when $\mathrm{BC}$ and $\mathrm{OC}$ emissions are halved together, suggesting that these results greatly underestimate the full air pollution-related mortality benefits of $\mathrm{BC}$ mitigation, which would affect emissions of multiple species simultaneously. Several studies have examined the net climate impacts of the total emission mixture from individual economic sectors, finding that for some sectors, cooling agents such as $\mathrm{SO}_{4}$ and $\mathrm{OM}$ offset the warming impacts of $\mathrm{BC}$ (e.g. Koch et al., 2007; Unger et al., 2010). Since no pollutant is beneficial for health, future studies should assess the health impacts of individual economic sectors and mitigation measures, accounting for the full mixture of emissions and both outdoor and indoor exposure. Confidence in our results would also be strengthened by reducing uncertainties from emissions, model parameterization of aerosol processes, grid resolution, and $\mathrm{PM}_{2.5}$ concentration-mortality relationships over a range of concentrations, component mixtures, and populations.

\section{Supplementary material related to this article is available online at: http://www.atmos-chem-phys.net/11/7253/2011/ acp-11-7253-2011-supplement.pdf.}

Acknowledgements. The opinions expressed in this article are the authors' and do not necessarily represent those of the US EPA. This work was supported in part by the EPA Office of Air Quality Planning and Standards and a grant from the National Institute of Environmental Health Sciences (P30ES10126). We thank L. Emmons, S. Walters, S. Liu, and Z. Adelman for assistance with MOZART-4, J. Liu for assistance with the model evaluation, and N. Frank, T. Rao, E. Sasser, B. Hubbell, D. Leith, W. Vizuete, and $\mathrm{K}$. Yeatts for valuable insights. We also thank the entire NCAR MOZART-4 development team for their efforts.

Edited by: M. Kopacz

\section{References}

Anenberg, S. C., West, J. J., Fiore, A. F., Jaffe, D. A., Prather, M. J., Bergmann, D., Cuvelier, K., Dentener, F. J., Duncan, B. N., Gauss, M., Hess, P., Jonson, J. E., Lupu, A., Mackenzie, I. A., Marmer, E., Park, R. J., Sanderson, M. G., Schultz, M., Shindell, D. T., Szopa, S., Vivanco M. G., Wild, O., and Zeng, G.: Intercontinental impacts of ozone air pollution on human mortality, Environ. Sci. Technol., 43, 6482-6487, 2009.

Anenberg, S. C., Horowitz, L. W., Tong, D. Q., and West, J. J.: An estimate of the global burden of anthropogenic ozone and fine particulate matter on premature human mortality using atmospheric modeling, Environ. Health Perspect., 118, 1189-1195, 2010.

Atkinson, R. W., Cohen, A., Mehta, S., and Anderson, H. R.: Systematic review and meta-analysis of epidemiological time-series studies on outdoor air pollution and health in Asia, Air Quality, Atmosphere \& Health, in press, doi:10.1007/s11869-010-01232, 2011 .

Barrett, S. R. H., Britter, R. E., and Waitz, I. A.: Global mortality attributable to aircraft cruise emissions, Environ. Sci. Technol., 44, 7736-7742, 2010.

Beegum, S. N., Moorthy, K. K., Babu, S. S., Satheesh, S. K., Vinoj, V., Badarinath, K. V. S., Safai, P. D., Devara, P. C. S., Singh, S., Vinod, Dumka, U. C., and Pant, P.: Spatial distribution of aerosol black carbon over India during pre-monsoon season, Atmos. Environ., 43, 1071-1078, 2009.

Bell, M. L., Ebisu, K., Peng, R. D., Samet, J. M., and Dominici, F.: Hospital admissions and chemical composition of fine particle air pollution, Am. J. Resp. Crit. Care, 179, 1115-1120, 2009.

Bell, M. L., Ebisu, K., and Peng, R. D.: Community-level spatial heterogeneity of chemical constituent levels of fine particulates and implications for epidemiological research, J. Expo. Sci. Env. Epid., 21, 372-387, 2011.

Bond, T. C. and Sun, H.: Can reducing black carbon emissions counteract global warming?, Environ. Sci. Technol., 39, 59215926, 2005.

Bond, T. C., Streets, D. G., Yarber, K. F., Nelson, S. M., Woo, J.H., and Klimont, Z.: A technology-based global inventory of 
black and organic carbon emissions from combustion, J. Geophys. Res., 109, D14203, doi:10.1029/2003JD003697, 2004.

Bond T. C., Bhardwaj, E., Dong, R., Jogani, R., Jung, S., Roden, C., Streets, D. G., and Trautmann, N. M.: Historical emissions of black and organic carbon aerosol from energy-related combustion, 1850-2000, Global Biogeochem. Cy., 21, GB2018, doi:10.1029/2006GB002840, 2007.

Brunekreef, B., Beelen, R., Hoek, G., Schouten, L., BauschGoldbohm, S., Fischer, P., Armstrong, B., Hughes, E., Jerrett, M., and van den Brandt, P.: Effects of Long-Term Exposure to Traffic-Related Air Pollution on Respiratory and Cardiovascular Mortality in the Netherlands: The NLCS-AIR Study. Health Effects Institute, Boston, MA, 2009.

Castro, T., Madronich, S., Rivale, S., Muhlia, A., and Mar, B.: The influence of aerosols on photochemical smog in Mexico City, Atmos. Environ., 35, 1765-1772, 2001.

Chow, J. C., Watson, J. G., Crow, D., Lowenthal, D. H., and Merrifield, T.: Comparison of IMPROVE and NIOSH carbon measurements, Aerosol Sci. Tech., 34, 23-34, 2001.

Cohen, A. J., Anderson, H. R., Ostro, B., Pandey, K. D., Krzyzanowski, M., Kunzli, N., Gutschmidt, K., Pope III, C. A., Romieu, I., Samet, J. M., and Smith, K. R.: Urban air pollution, in: Comparative Quantification of Health Risks: Global and Regional Burden of Disease Due to Selected Major Risk Factors, edited by: Ezzati, M., Lopez, A. D., Rodgers, A., and Murray, C. J. L., Geneva: World Health Organization, 1353-1434, 2004.

Cooke, W. F., Liousse, C., Cachier, H., and Feichter, J.: Construction of a $1^{\circ} \times 1^{\circ}$ fossil fuel emission data set for carbonaceous aerosol and implementation and radiative impact in the ECHAM4 model, J. Geophys. Res., 104, 22137-22162, 1999.

Cooke, R. M., Wilson, A. M., Tuomisto, J. T., Morales, O., Tainio, M., and Evans, J. S.: A probabilistic characterization of the relationship between fine particulate matter and mortality: Elicitation of European experts, Environ. Sci. Technol., 41, 6598-6605, 2007.

Corbett, J. J., Winebrake, J. J., Green, E. H., Kasibhatla, P., Eyring, V., and Lauer, A.: Mortality from ship emissions: A global assessment, Environ. Sci. Technol., 41, 8512-8518, 2007.

Dentener, F., Kinne, S., Bond, T., Boucher, O., Cofala, J., Generoso, S., Ginoux, P., Gong, S., Hoelzemann, J. J., Ito, A., Marelli, L., Penner, J. E., Putaud, J.-P., Textor, C., Schulz, M., van der Werf, G. R., and Wilson, J.: Emissions of primary aerosol and precursor gases in the years 2000 and 1750 prescribed data-sets for AeroCom, Atmos. Chem. Phys., 6, 4321-4344, doi:10.5194/acp6-4321-2006, 2006.

Dickerson, R. R., Kondragunta, S., Stenchikov, G., Civerolo, K. L., Doddridge, B. G., and Holben, B. N.: The impact of aerosols on solar ultraviolet radiation and photochemical smog, Science, 278, 827-830, 1997.

Dickerson, R. R., Andreae, M. O., Campos, T., Mayol-Bracero, O. L., Neusuess, C., and Streets, D. G.: Analysis of black carbon and carbon monoxide observed over the Indian Ocean: Implications for emissions and photochemistry, J. Geophys. Res., 107(D19), 8017, doi:10.1029/2001JD000501, 2002.

Dominici, F., Peng, R. D., Barr, C. D., and Bell, M. L.: Protecting human health from air pollution: Shifting from a single-pollutant to a multipollutant approach, Epidemiology, 21, 187-194, 2010.

Duncan, B. N., West, J. J., Yoshida, Y., Fiore, A. M., and Ziemke, J. R.: The influence of European pollution on ozone in the Near
East and northern Africa, Atmos. Chem. Phys., 8, 2267-2283, doi:10.5194/acp-8-2267-2008, 2008.

Dunlea, E. J., DeCarlo, P. F., Aiken, A. C., Kimmel, J. R., Peltier, R. E., Weber, R. J., Tomlinson, J., Collins, D. R., Shinozuka, Y., McNaughton, C. S., Howell, S. G., Clarke, A. D., Emmons, L. K., Apel, E. C., Pfister, G. G., van Donkelaar, A., Martin, R. V., Millet, D. B., Heald, C. L., and Jimenez, J. L.: Evolution of Asian aerosols during transpacific transport in INTEX-B, Atmos. Chem. Phys., 9, 7257-7287, doi:10.5194/acp-9-7257-2009, 2009.

Emmons, L. K., Apel, E. C., Lamarque, J.-F., Hess, P. G., Avery, M., Blake, D., Brune, W., Campos, T., Crawford, J., DeCarlo, P. F., Hall, S., Heikes, B., Holloway, J., Jimenez, J. L., Knapp, D. J., Kok, G., Mena-Carrasco, M., Olson, J., O'Sullivan, D., Sachse, G., Walega, J., Weibring, P., Weinheimer, A., and Wiedinmyer, C.: Impact of Mexico City emissions on regional air quality from MOZART-4 simulations, Atmos. Chem. Phys., 10, 6195-6212, doi:10.5194/acp-10-6195-2010, 2010a.

Emmons, L. K., Walters, S., Hess, P. G., Lamarque, J.-F., Pfister, G. G., Fillmore, D., Granier, C., Guenther, A., Kinnison, D., Laepple, T., Orlando, J., Tie, X., Tyndall, G., Wiedinmyer, C., Baughcum, S. L., and Kloster, S.: Description and evaluation of the Model for Ozone and Related chemical Tracers, version 4 (MOZART-4), Geosci. Model Dev., 3, 43-67, doi:10.5194/gmd3-43-2010, 2010b.

Fuglestvedt, J. S., Shine, K. P., Bernsten, T., Cook, J., Lee, D. S., Stenke, A., Skeie, R. B., Velders, G. J. M., and Waitz, I. A.: Transport impacts on atmosphere and climate: Metrics, Atmos. Environ., 44, 4648-4677, 2010.

Granier, C., Lamarque, J. F., Mieville, A., Muller, J. F., Olivier, J., Orlando, J., Peters, J., Petron, G., Tyndall, G., and Wallens, S.: POET, a database of surface emissions of ozone precursors, available at: http://accent.aero.jussieu.fr/POET_metadata. php, 2005.

Gilardoni, S., Vignati, E., and Wilson, J.: Using measurements for evaluation of black carbon modeling, Atmos. Chem. Phys., 11, 439-455, doi:10.5194/acp-11-439-2011, 2011.

Hansen, J. and Nazarenko, L.: Soot climate forcing via snow and ice albedos, P. Natl. Acad. Sci., 101, 423-428, 2004.

He, S. and Carmichael, G. R.: Sensitivity of photolysis rates and ozone production in the troposphere to aerosol properties, J. Geophys. Res., 104, 26307-26324, 1999.

HEI Public Health and Air Pollution in Asia Program (HEI): Public Health and Air Pollution in Asia (PAPA): Coordinated Studies of Short-Term Exposure to Air Pollution and Daily Mortality in Four Cities. HEI Research Report 154. Health Effects Institute, Boston, MA, 2010.

Horvath, H.: Atmospheric light absorption - A review, Atmos. Environ., 27, 293-317, 1993.

Industrial Economics, Incorporated (IEc): Uncertainty Analyses to Support the Second Section 812 Benefit-Cost Analysis of the Clean Air Act, Draft Report. US Environmental Protection Agency, Washington, DC, 2010.

Jacobson, M. Z.: Studying the effects of aerosols on vertical photolysis rate coefficient and temperature profiles over an urban airshed, J. Geophys. Res., 103, 10593-10604, 1998.

Jacobson, M. Z.: Control of fossil-fuel particulate black carbon and organic matter, possibly the most effective method of slowing global warming, J. Geophys. Res., 107(D19), 4410, 
doi:10.1029/2001JD001376, 2002.

Jacobson, M. Z.: On the causal link between carbon dioxide and air pollution mortality, Geophys. Res. Lett., 35, L03809, doi:10.1029/2007GL031101, 2008.

Jacobson, M. Z.: Short-term effects of controlling fossil-fuel soot, biofuel soot and gases, and methane on climate, Arctic ice, and air pollution health, J. Geophys. Res., 115, D14209, doi.10.1029/2009JD013795, 2010.

Junker, C. and Liousse, C.: A global emission inventory of carbonaceous aerosol from historic records of fossil fuel and biofuel consumption for the period 1860-1997, Atmos. Chem. Phys., 8, 1195-1207, doi:10.5194/acp-8-1195-2008, 2008.

Kalnay, E., Kanamitsu, M., Kistler, R., Collins, W., Deaven, D., Gandin, L., Iredell, M., Saha, S., White, G., Woollen, J., Zhu, Y., Chelliah, M., Ebisuzaki, W., Higgins, W., Janowiak, J., Mo, K. C., Ropelewski, C., Wang, J., Leetmaa, A., Reynolds, R., Jenne, R., and Joseph, D.: The NCEP/NCAR 40-Year Reanalysis Project, B. Am. Meteorol. Soc., 77, 437-471, 1996.

Kistler, R., Kalnay, E., Collins, W., Saha, S., White, G., Woollen, J., Chelliah, M., Ebisuzaki, W., Kanamitsu, M., Kousky, V., van den Dool, H., Jenne, R., and Fiorino, M.: The NCEP-NCAR 50-Year Reanalysis: Monthly Means CD-ROM and Documentation, B. Am. Meteorol. Soc., 82, 247-268, 2001.

Koch, D. and Del Genio, A. D.: Black carbon semi-direct effects on cloud cover: review and synthesis, Atmos. Chem. Phys., 10, 7685-7696, doi:10.5194/acp-10-7685-2010, 2010.

Koch, D., Bond, T. C., Streets, D., Unger, N., and van der Werf, G. R.: Global impacts of aerosols from particular source regions and sectors, J. Geophys. Res., 112, D02205, doi:10.1029/2005JD007024, 2007.

Koch, D., Schulz, M., Kinne, S., McNaughton, C., Spackman, J. R., Balkanski, Y., Bauer, S., Berntsen, T., Bond, T. C., Boucher, O., Chin, M., Clarke, A., De Luca, N., Dentener, F., Diehl, T., Dubovik, O., Easter, R., Fahey, D. W., Feichter, J., Fillmore, D., Freitag, S., Ghan, S., Ginoux, P., Gong, S., Horowitz, L., Iversen, T., Kirkevåg, A., Klimont, Z., Kondo, Y., Krol, M., Liu, X., Miller, R., Montanaro, V., Moteki, N., Myhre, G., Penner, J. E., Perlwitz, J., Pitari, G., Reddy, S., Sahu, L., Sakamoto, H., Schuster, G., Schwarz, J. P., Seland, Ø., Stier, P., Takegawa, N., Takemura, T., Textor, C., van Aardenne, J. A., and Zhao, Y.: Evaluation of black carbon estimations in global aerosol models, Atmos. Chem. Phys., 9, 9001-9026, doi:10.5194/acp-9-9001-2009, 2009.

Kopp, R. E. and Mauzerall, D. L.: Assessing the climatic benefits of black carbon mitigation, P. Natl. Acad. Sci., 26, 11703-11708, 2010.

Krewski, D., Jerrett, M., Burnett, R. T., Ma, R., Hughes, E., Shi, Y., Turner, M. C., Pope III, C. A., Thurston, G., Calle, E. E., and Thun, M. J.: Extended Follow-Up and Spatial Analysis of the American Cancer Society Study Linking Particulate Air Pollution and Mortailty, HEI Research Report 140, Health Effects Institute, Boston, MA, 2009.

Laden, F., Schwartz, J., Speizer, F. E., and Dockery, D. W.: Reduction in fine particulate air pollution and mortality: Extended follow-up of the Harvard Six Cities Study, Am. J. Resp. Crit. Care, 173, 667-672, 2006.

Lamarque, J.-F., Bond, T. C., Eyring, V., Granier, C., Heil, A., Klimont, Z., Lee, D., Liousse, C., Mieville, A., Owen, B., Schultz, M. G., Shindell, D., Smith, S. J., Stehfest, E., Van
Aardenne, J., Cooper, O. R., Kainuma, M., Mahowald, N., McConnell, J. R., Naik, V., Riahi, K., and van Vuuren, D. P.: Historical (1850-2000) gridded anthropogenic and biomass burning emissions of reactive gases and aerosols: methodology and application, Atmos. Chem. Phys., 10, 7017-7039, doi:10.5194/acp10-7017-2010, 2010.

Levy II, H., Schwarzkopf, M. D., Horowitz, L., Ramaswamy, V., and Findell, K. L.: Strong sensitivity of late 21 st century climate to projected changes in short-lived air pollutants, J. Geophys. Res., 113, D06102, doi:10.1029/2007JD009176, 2008.

Li, G., Zhang, R., Fan, J., and Tie, X.: Impacts of black carbon aerosol on photolysis and ozone, J. Geophys. Res., 110, D23206, doi:10.1029/2005JD005898, 2005.

Liao, H., Yung, Y. L., and Seinfeld, J. H.: Effects of aerosols on tropospheric photolysis rates in clear and cloudy atmospheres, J. Geophys. Res., 104, 23697-23707, 1999.

Liu, J., Mauzerall, D. L., and Horowitz, L. W.: Evaluating intercontinental transport of fine aerosols: (2) Global health impact. Atmos. Environ., 43, 4339-4347, 2009a.

Liu, J., Mauzerall, D. L., Horowitz, L. W., Ginoux, P., and Fiore, A. M.: Evaluating inter-continental transport of fine aerosols: (1) Methodology, global aerosol distribution and optical depth, Atmos. Environ., 43, 4327-4338, 2009 b.

Martin, R. V., Jacob, D. J., Yantosca, R. M., Chin, M., and Ginoux, P.: Global and regional decreases in tropospheric oxidants from photochemical effects of aerosols, J. Geophys. Res., 108(D3), 4097, doi:10.1029/2002JD002622, 2003.

Ming, Y., Ramaswamy, V., Ginoux, P. A., and Horowitz, L. H.: Direct radiative forcing of anthropogenic organic aerosol. J. Geophys. Res., 110, D20208, doi:10.1029/2004JD005573, 2005.

Novakov, T., Menon, S., Kirchstetter, T. W., Koch, D., and Hansen, J. E.: Aerosol organic carbon to black carbon ratios: Analysis of published data and implications for climate forcing, J. Geophys. Res., 110, D21205, doi:10.1029/2005JD005977, 2005.

Oak Ridge National Laboratory: LandScan Global Population Database 2006, available at: http://www.ornl.gov/sci/landscan/ index.html, 2008.

Ohara, T., Akimoto, H., Kurokawa, J., Horii, N., Yamaji, K., Yan, X., and Hayasaka, T.: An Asian emission inventory of anthropogenic emission sources for the period 1980-2020, Atmos. Chem. Phys., 7, 4419-4444, doi:10.5194/acp-7-4419-2007, 2007.

Olivier, J., Peters, J., Granier, C., Petron, G., Muller, J., and Wallens, S.: Present and future surface emissions of atmospheric compounds, POET report \#2, EU project EVK2-1999-00011, available at: http://accent.aero.jussieu.fr/POET_metadata.php, 2003.

Ostro, B., Feng, W. Y., Broadwin, R., Green, S., and Lipsett, M.: The effects of components of fine particulate air pollution on mortality in California: Results from CALFINE, Environ. Health Perspect., 115, 13-19, 2007.

Ostro, B. D., Feng, W.-Y., Broadwin, R., Malig, B. J., Green, R. S., and Lipsett, M. J.: The impact of components of fine particulate matter on cardiovascular mortality in susceptible subpopulations, Occup. Environ. Med., 65, 750-756, 2008.

Park, R. J., Daniel, J. J., Field, B. D., Yantosca, R. M., and Chin, M.: Natural and transboundary pollution influences on sulfate-nitrate-ammonium aerosols in the United States: Implications for policy, J. Geophys. Res., 109, D15204, 
doi:10.1029/2003JD004473, 2004.

Peng, R. D., Bell, M. L., Geyh, A. S., McDermott, A., Zeger, S. L., Samet, J. M., and Dominici, F.: Emergency admissions for cardiovascular and respiratory diseases and the chemical composition of fine particle air pollution, Environ. Health Perspect., 117, 957-963, 2009.

Pope III, C. A., Burnett, R. T., Thun, M. J., Calle, E. E., Krewski, D., Ito, K., and Thurston, G.: Lung cancer, cardiopulmonary mortality, and long-term exposure to fine particulate air pollution, JAMA-J. Am. Med. Assoc., 287, 1132-1141, 2002.

Pope III, C. A. , Burnett, R. T., Krewski, D., Jerrett, M., Shi, Y., Calle, E. E., and Thun, M. J.: Cardiovascular mortality and exposure to airborne fine particulate matter and cigarette smoke: Shape of the exposure-response relationship, Circulation, 120, 941-948, 2009.

Ramanathan, V. and Carmichael, G.: Global and regional climate changes due to black carbon, Nature, 1, 221-227, 2008.

Reddy, M. S. and Boucher, O.: Climate impact of black carbon emitted from energy consumption in the world's regions, Geophys. Res. Lett., 34, L11802, doi:10.1029/2006GL028904, 2007.

Selin, N. E., Wu, S., Nam, K. M., Reilly, J. M., Paltsev, S., Prinn, R. G., and Webster, M. D.: Global health and economic impacts of future ozone pollution, Environ. Res. Lett., 4, 044014, doi:10.1088/1748-9326/4/4/044014, 2009.

Shindell, D. T., Levy, H. II, Schwarzkopf, M. D., Horowitz, L. W., Lamarque, J.-F., and Faluvegi, G.: Multimodel projections of climate change from short-lived emissions due to human activities, J. Geophys. Res., 113, D11109, doi:10.1029/2007JD009152, 2008.

Smith, K. R. and Peel, J. L.: Mind the gap, Environ. Health Perspect., 118, 1643-1645, 2010.

Smith, K. R., Mehta, S., Maeusezahl-Feuz, M.: Indoor air pollution from household use of solid fuelds, in: Comparative Quantification of Health Risks: Global and Regional Burden of Disease Due to Selected Major Risk Factors, edited by: Ezzati, M., Lopez, A. D., Rodgers, A., and Murray, C. J. L., Geneva: World Health Organization, 1415-1493, 2004.

Smith, K. R., Jerrett, M., Anderson, H. R., Burnett, R. T., Stone, V., Derwent, R., Atkinson, R. W., Cohen, A., Shonkoff, S. B., Krewski, D., Pope III, C. A. , Thun, M. J., and Thurston, G.: Public health benefits of strategies to reduce greenhouse-gas emissions: health implications of short-lived greenhouse pollutants, Lancet, 374, 2091-2103, 2009.

Swall, J. L. and Foley, K. M.: The impact of spatial correlation and incommensurability on model evaluation, Atmos. Environ., 43, 1204-1217, 2009.
Task Force on Hemispheric Transport of Air Pollution (TF HTAP): Hemispheric Transport of Air Pollution 2010, in: Air Pollution Studies, No. 16. United National Economic Commission for Europe, New York and Geneva, 2010.

Tie, X., Brasseur, G., Emmons, L., Horowitz, L., and Kinnison, D.: Effects of aerosols on tropospheric oxidants: A global model study, J. Geophys. Res., 106(D19), 22931-22964, doi:10.1029/2001JD900206, 2001.

Tie, X., Madronich, S., Walters, S., Edwards, D. P., Ginoux, P., Mahowald, N., Zhang, R. Y., Lou, C., and Brasseur, G.: Assessment of the global impact of aerosols on tropospheric oxidants, J. Geophys. Res., 110, D03204, doi:10.1029/2004JD005359, 2005.

Unger, N., Bond, T. C., Wang, J. S., Koch, D. M., Menon, S., Shindell, D. T., and Bauer, S.: Attribution of climate forcing to economic sectors, P. Natl. Acad. Sci., 107, 3382-3387, 2010.

van der Werf, G. R., Randerson, J. T., Giglio, L., Collatz, G. J., Kasibhatla, P. S., and Arellano Jr., A. F.: Interannual variability in global biomass burning emissions from 1997 to 2004, Atmos. Chem. Phys., 6, 3423-3441, doi:10.5194/acp-6-3423-2006, 2006.

Vedal, S. and Kaufman, J. D.: What does multi-pollutant air pollution research mean?, Am. J. Resp. Crit. Care, 183, 4-6, 2011.

Vignati, E., Karl, M., Krol, M., Wilson, J., Stier, P., and Cavalli, F.: Sources of uncertainties in modelling black carbon at the global scale, Atmos. Chem. Phys., 10, 2595-2611, doi:10.5194/acp-102595-2010, 2010.

West, J. J., Fiore, A. M., Horowitz, L. W., and Mauzerall, D. L.: Global health benefits of mitigating ozone pollution with methane emission controls, P. Natl. Acad. Sci., 103, 3988-3993, 2006.

West, J. J., Szopa, S., and Hauglustaine, D. A.: Human mortality effects of future concentrations of tropospheric ozone, C. R. Geosci., 339, 775-783, 2007.

West, J. J., Naik, V., Horowitz, L. W., and Fiore, A. M.: Effect of regional precursor emission controls on long-range ozone transport - Part 2: Steady-state changes in ozone air quality and impacts on human mortality, Atmos. Chem. Phys., 9, 6095-6107, doi:10.5194/acp-9-6095-2009, 2009.

WHO (World Health Organization): The World Health Report 2004: Changing History, Geneva, 2004.

WHO (World Health Organization): WHO Mortality Database: Tables, Geneva, available at: http://www.who.int/healthinfo/ morttables/en/index.html, 2008.

Zhang, X. Y., Wang, Y. Q., Zhang, X. C., Guo, W., and Gong, S. L.: Carbonaceous aerosol composition over various regions of China during 2006, J. Geophys. Res., 113, D14111, doi:10.1029/2007JD009525, 2008. 